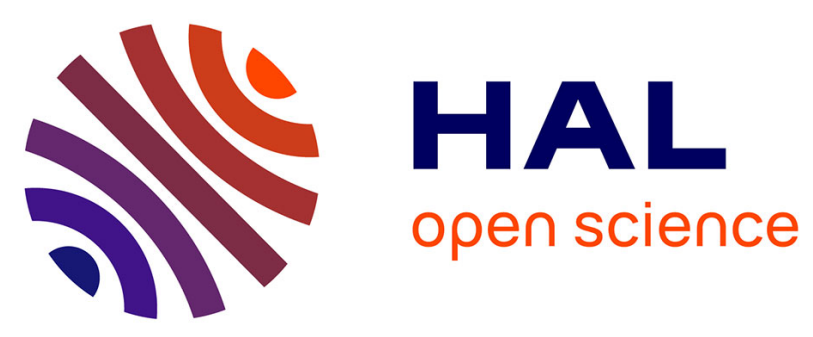

\title{
Field performance of two biofiltration systems treating micropollutants from road runoff
}

\author{
Kelsey Flanagan, Philippe Branchu, Lila Boudahmane, Emilie Caupos, \\ Dominique Demare, Steven Deshayes, Philippe Dubois, Laurent Meffray, \\ Chandirane Partibane, Mohamed Saad, et al.
}

\section{To cite this version:}

Kelsey Flanagan, Philippe Branchu, Lila Boudahmane, Emilie Caupos, Dominique Demare, et al.. Field performance of two biofiltration systems treating micropollutants from road runoff. Water Research, 2018, 145, pp.562-578. 10.1016/j.watres.2018.08.064 . hal-02065407

\section{HAL Id: hal-02065407 \\ https: / hal-enpc.archives-ouvertes.fr/hal-02065407}

Submitted on 12 Mar 2019

HAL is a multi-disciplinary open access archive for the deposit and dissemination of scientific research documents, whether they are published or not. The documents may come from teaching and research institutions in France or abroad, or from public or private research centers.
L'archive ouverte pluridisciplinaire HAL, est destinée au dépôt et à la diffusion de documents scientifiques de niveau recherche, publiés ou non, émanant des établissements d'enseignement et de recherche français ou étrangers, des laboratoires publics ou privés. 
Field performance of two biofiltration systems treating micropollutants from road runoff

Kelsey Flanagan ${ }^{1, *}$, Philippe Branchu ${ }^{2}$, Lila Boudahmane ${ }^{1}$, Emilie Caupos ${ }^{1}$, Dominique Demare ${ }^{3}$, Steven Deshayes ${ }^{1}$, Philippe Dubois ${ }^{1}$, Laurent Meffray ${ }^{2}$, Chandirane Partibane ${ }^{1}$, Mohamed Saad ${ }^{1}$, MarieChristine Gromaire ${ }^{1}$

${ }^{1}$ LEESU, UMR MA 102, École des Ponts, AgroParisTech, UPEC, UPE, Champs-sur-Marne, 6-8 avenue Blaise Pascal, Cité Descartes, 77455 Marne-la-Vallée Cedex 2, France. kelsey.flanagan@enpc.fr

${ }^{2}$ CEREMA, 12 Rue Léon Teisserenc de Bort, 78190 Trappes, France. philippe.branchu@cerema.fr

${ }^{3}$ IFSTTAR, Laboratoire Eau et Environnement- route de Bouaye CS4 - 44344 Bouguenais Cedex, France.

${ }^{*}$ Corresponding author

\section{Abstract :}

The treatment efficiency of a vegetative filter strip and a biofiltration swale treating heavily loaded road runoff are evaluated. Concentrations measured in water drained from the two systems are compared to those in untreated road runoff collected from a reference catchment for a wide range of contaminants including organic carbon, nutrients ( $\mathrm{N}$ and $\mathrm{P}$ ), metallic trace elements, and organic micropollutants (polycyclic aromatic hydrocarbons (PAH), total petroleum hydrocarbons (TPH), alkylphenols, bisphenol-A, phthalates), in both total and dissolved phases. Predominantly particulate pollutants, including $\mathrm{Pb}, \mathrm{Zn}$ and $\mathrm{PAH}$, were very efficiently removed (around $90 \%$ ) for most events. However, poor particulate removal was observed during a winter period. Relatively few pollutants were significantly removed in the dissolved phase and observed concentration reductions tended to be lower than those of suspended solids and associated pollutants; as such, lower removals were observed for total concentrations of moderately particulate micropollutants, including bisphenol-A, alkylphenols and phthalates. In addition, some pollutants appear to be emitted from various biofilter components (filter media, drainage and lining materials), as low or negative concentration removals were observed during the first months of operation of the biofiltration swale.

Keywords: Biofiltration, swale, vegetative filter strip, road runoff, micropollutant, low impact development

Declaration of interest: none 


\section{Introduction}

The creation of impermeable surfaces associated with urbanization poses a threat to aquatic ecosystems due to both increased runoff flows and water quality degradation. Road runoff, in particular, has long been considered to be particularly polluted by a range of contaminants including total suspended solids (TSS), nutrients, total petroleum hydrocarbons (TPH), trace metals and polycyclic aromatic hydrocarbons (PAH) (Brown and Peake, 2006; Huber et al., 2016; Kayhanian et al., 2012).

More recently, research has demonstrated the presence of a wider range of organic micropollutants, including alkylphenols, phthalates, bisphenol-A (BPA) and pesticides, some of which are considered priority substances in the European Water Framework Directive (EC, 2013), in urban (Bressy et al., 2012; Gasperi et al., 2014; Zgheib et al., 2012) and road runoff (Björklund et al., 2009).

Within this context, new paradigms, referred to as low impact development (LID), sustainable drainage systems (SuDS) or water sensitive urban design (WSUD), have emerged for managing urban stormwater close to the source. These approaches often rely on localized, vegetated systems that are designed to achieve multiple objectives, such as restoring the hydrologic balance of a site to that before development, improving water quality and contributing to the urban landscape and biodiversity (Fletcher et al., 2014).

One technique often employed when water quality improvement is a priority is that of bioretention or biofiltration, consisting of a vegetated depression that receives and stores runoff water, which then filters through a filter media made of engineered soil, before being collected by an underdrain or exfiltrated to the surrounding soil (Davis et al., 2009; Roy-Poirier et al., 2010). These systems may also be referred to as rain gardens or, if in a linear form, as biofiltration swales or bioswales.

In other LID devices, such as vegetative filter strips and grassed swales, generally designed to transport and pretreat water at the surface but in which large proportions of runoff may infiltrate for common, low-intensity rain events (Flanagan et al., 2017), infiltrated water is depolluted by processes analogous to those occurring in bioretention systems. In all of these systems, which for the purposes of this paper will both be regrouped under the term biofilter, particulate pollutants are expected to be removed through sedimentation and physical filtration and dissolved pollutants through various processes, including sorption, biodegradation, volatilization and plant uptake (LeFevre et al., 2014).

The efficiency of these systems at treating conventional pollutants, such as TSS, nitrogen, phosphorus and trace metals, has been well documented (Brown and Hunt, 2011; Davis, 2007; Hatt et al., 2009; Hsieh and Davis, 2005; Hunt et al., 2006, 2008; Li and Davis, 2009; Trowsdale and Simcock, 2011). However, only a few of these studies (David et al., 2015; Li and Davis, 2009; Trowsdale and Simcock, 2011) distinguish the dissolved phase of any trace metals. While the generally efficient removal of TSS indicates that the particulate fractions of pollutants are likely to be well removed, the in situ behavior of dissolved pollutants, which are more biologically available, subject to different removal processes and likely more mobile than their particulate counterparts, remains obscure (LeFevre et al., 2014).

In addition, relatively few studies have considered the treatment efficiency of organic micropollutants. Although two biofiltration systems evaluated by Zhang et al. (2014) demonstrated high removal efficiencies for a wide range of organic micropollutants, including TPH, PAH, herbicides, phthalates, trihalomethanes and phenols, using in situ columns and synthetic runoff, few micropollutants have been studied in biofiltration systems using real runoff. Indeed, among a hierarchy of priority micropollutants associated with road runoff $\left(\mathrm{PAH}>\right.$ alkanes $\left(\mathrm{C}_{20}-\mathrm{C}_{40}\right)>$ alkylphenols $>$ phthalates $>$ aldehydes $>$ phenolic antioxidants $>$ bisphenol A (BPA) > oxygenated PAH 
$>$ naphtha $\mathrm{C}_{5}-\mathrm{C}_{12}>$ amides > amines) identified by Markiewicz et al. (2017), only PAH have been addressed by in situ studies of biofiltration treatment efficiency for real rain events (David et al., 2015; DiBlasi et al., 2009; Leroy et al., 2016). Beyond this list, David et al. (2015) also considered the behavior of polychlorinated biphenyls and dioxin. None of these studies distinguished the dissolved fraction of organic micropollutants.

The goal of the present work is to evaluate the in situ treatment performance of two biofilters receiving road runoff, a biofiltration swale and a vegetative filter strip, for previously studied pollutants (TSS, nutrients, trace metals, major elements and PAH) as well as emerging micropollutants as yet uncharacterized by field studies of biofiltration (BPA, alkylphenols, and phthalates). In order to improve scientific understanding of biofiltration performance for dissolved pollutants, efficiencies are reported for both the total and dissolved phases of pollutants.

2. Material and Methods

\subsection{Experimental site description}

The experimental site consists of a heavily trafficked (11 000 vehicles/day/direction) 4-lane highway and its drainage systems (Figure 1). The road, RD 212, was redeveloped in 2012, is made of asphalt sealed with bitumen and is in good condition. It is located in an industrial zone of Compans, France, a community near Charles de Gaulle Airport in the Paris metropolitan area and has a speed limit of 90 $\mathrm{km} / \mathrm{h}$. The industrial zone includes gas storage and conditioning, hydrocarbon storage and distribution, polymer fabrication and dangerous waste treatment activities, all of which are separated from the study site by several hundred meters and a line of trees. This region has a warm temperate climate with no dry season (Peel et al., 2007), receives an average of $637 \mathrm{~mm}$ of rainfall per year over an average of 111 days of precipitation $(>1 \mathrm{~mm})$ and experiences 25 days of freezing temperatures per year (Agence Parisienne du Climat and Météo-France, 2015).

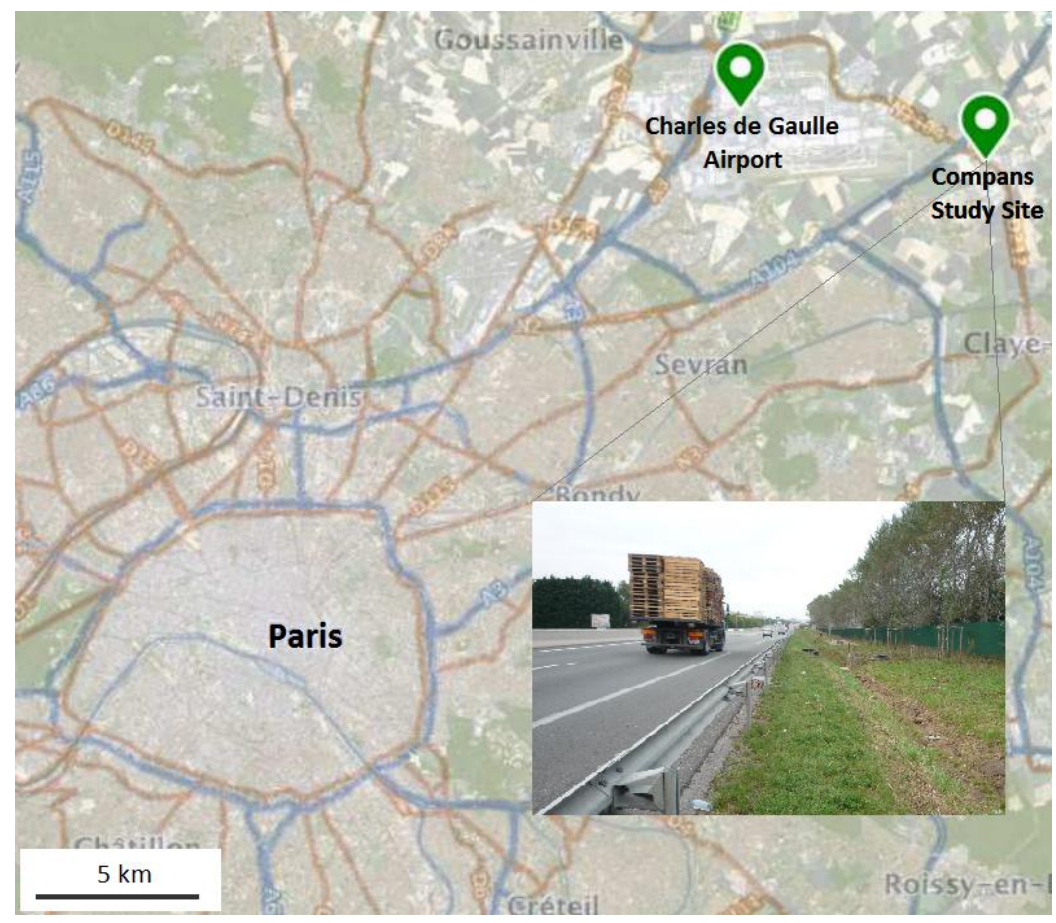

Figure 1: Map of the Compans study site location

Two linear biofilters, a vegetative filter strip (VFS) and a biofiltration swale (BFS), are studied (Figure 2). Both are located on the road shoulder and receive direct runoff from a single direction of traffic. The VFS was constructed in September 2012 and planted with a floral prairie seed mixture. Infiltrated water is drained at a depth of $15 \mathrm{~cm}$ using a sheet drain. The BFS was constructed in March 2016 and 
planted with Carex gracilis. The swale is separated into three sections using small, concrete check dams; the average ponding depth is $17 \mathrm{~cm}$. It is lined with a geomembrane and drained with an agricultural drain wrapped in synthetic fabric located at the base of its filter medium at a depth of 50 $\mathrm{cm}$. The filter media of both devices were prepared by mixing $40 \%$ silt loam topsoil with $60 \% 0-4 \mathrm{~mm}$ limestone sand by volume. Therefore, the two media have similar properties (Table 1), although higher organic content and lower pH are observed in the VFS, likely an effect of system aging.

\begin{tabular}{|l|c|c|}
\hline & Vegetative filter strip & Biofiltration swale \\
\hline Texture & Sandy loam & Sandy loam \\
\hline $\mathrm{pH}_{\text {water }}$ & 8.64 & 8.73 \\
\hline Organic carbon content (by mass, \%) & 2.4 & 0.9 \\
\hline Hydraulic conductivity $(\mathrm{mm} / \mathrm{h})$ & 24 & 21 \\
\hline Filter media depth $(\mathrm{cm})$ & 15 & 50 \\
\hline Ponding depth $(\mathrm{cm})$ & - & 17 \\
\hline Width (perpendicular to road, $\mathrm{m})$ & 1.8 & 0.5 \\
\hline Length (parallel to road, $\mathrm{m})$ & 48 & 32 \\
\hline $\begin{array}{l}\text { Surface area ratio } \\
\left(\mathrm{A}_{\text {device}} / \mathrm{A}_{\text {impermeable catchment }} \%\right)\end{array}$ & 17 & 4.5 \\
\hline
\end{tabular}

Table 1: Filter media and geometric properties of the two sustainable drainage systems

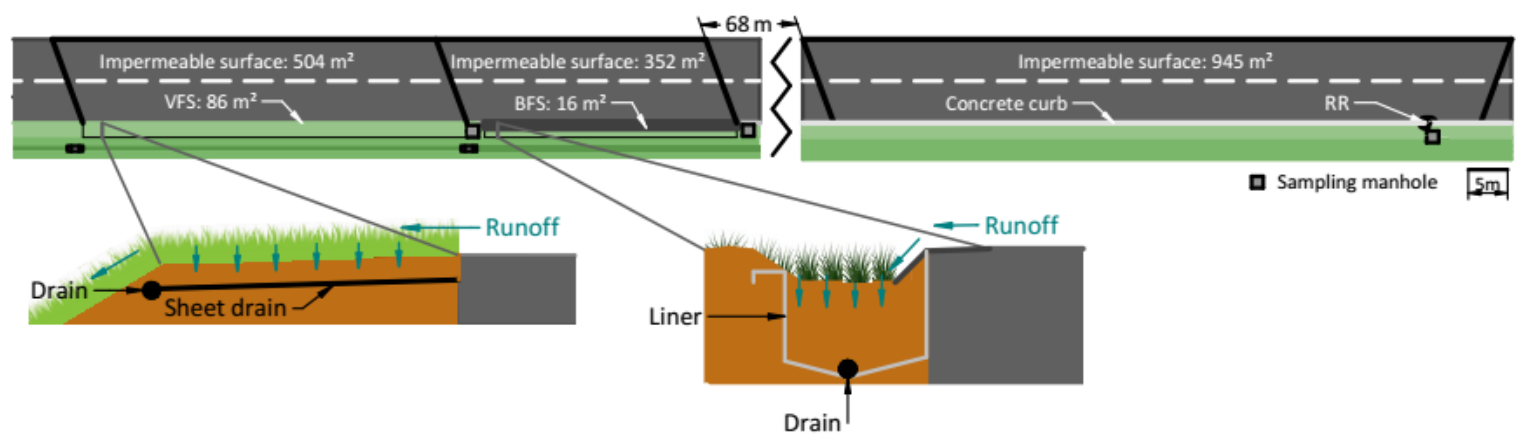

Figure 2: Schema of the Compans study site

Another portion of the RD 212, where runoff is directed towards a manhole along a concrete curb, is studied as a reference catchment. This portion, located on the same side of the road, $68 \mathrm{~m}$ from the edge of the BFS catchment, is made of the same asphalt in similar condition, has a similar slope, identical traffic and is subject to similar rain and sun exposure as the other catchments. Runoff from this segment represents untreated road runoff in a traditional drainage system.

\subsection{Field methods}

Stormwater was collected at three points representing untreated road runoff (RR) from the reference watershed, water drained from the vegetative filter strip (VFS) and water drained from the biofiltration swale (BFS).

At each point, flow was continuously measured using a tipping bucket flow meter (17L bucket volume at RR and $1 \mathrm{~L}$ volume at BFS and VFS). Flow proportional event mean samples were collected using two refrigerated automatic samplers at RR and passive flow dividers (tubes placed so as to collect a known fraction of each bucket tip) at VFS and BFS (see Supplementary Information for further description).

Materials in contact with sampled water were chosen carefully to avoid contamination. All tubing was coated in Teflon, and for each event, samples were collected in plastic bottles for metal, major 
element, nutrient and global parameter analyses, and in glass bottles for organic micropollutant analyses. Between each event, all bottles were washed with detergent (Extran for plastic bottles, TDF4 for glass bottles), rinsed several times with tap water, thrice with deionized water and twice with ultrapure water.

Field blanks were analyzed to verify that sampling equipment or procedures did not lead to sample contamination (Supplementary Data). While contamination was negligible for most species, slight but analytically significant increases (5-13\% of median dissolved concentration) in As, Cu, V, Zn and $\mathrm{NP}_{1} \mathrm{EC}$ and a larger increase (67\%) of Mo were observed from RR sampling equipment. Although an initial RR campaign during which water was left to stagnate $4 \mathrm{~h}$ in the equipment showed contamination by all phthalate molecules, a second campaign, conducted under more realistic flow conditions, showed no contamination.

Sampling equipment was deployed in response to meteorological predictions of significant $(>2 \mathrm{~mm})$ rainfall and samples collected within $36 \mathrm{~h}$ of the beginning of rainfall for the targeted runoff event, with the exception of one exceptionally long, continuous event lasting $40 \mathrm{~h}$, and within $24 \mathrm{~h}$ of the end of RR runoff to ensure adequate sample conservation.

A total of 19 sampling campaigns were undertaken between February 2016 and July 2017, covering all four seasons and various hydrologic conditions (Table 2). While the goal was to collect inlet and outlet samples simultaneously, due to the later construction of the BFS and various technical difficulties, not all samples were available for each sampling period: 14, 15, and 18 samples were collected for RR, BFS and VFS, respectively. Sampling efficiency (the proportion of each event volume represented in the event mean sample) is discussed in Supplementary Information.

\begin{tabular}{|l|c|}
\hline & Median (min, max) \\
\hline Total Rainfall $(\mathrm{mm})$ & $7.8(1.6,47.2)$ \\
\hline Maximal Intensity $(6$ minute time step, $\mathrm{mm} / \mathrm{h})$ & $11(2,43)$ \\
\hline Mean Intensity $(\mathrm{mm} / \mathrm{h})$ & $0.47(0.06,2.25)$ \\
\hline Rain event duration $(\mathrm{h})$ & $18.6(2.0,40.0)$ \\
\hline Antecedent dry period (days) & $1.0(0.1,17.7)$ \\
\hline
\end{tabular}

Table 2: Sampled rain event characteristics

\subsection{Analytical methods}

Samples were analyzed for a range of global parameters, including $\mathrm{pH}$, electrical conductivity $(\mathrm{EC})$, turbidity, total suspended solids (TSS), organic carbon (OC), nutrients ( $\mathrm{N}$ and $\mathrm{P}$ forms), as well as 12 trace metals, 9 major elements, $\mathrm{C}_{10}-\mathrm{C}_{40}$ hydrocarbons (TPH), 19 polycyclic aromatic hydrocarbons (PAH), bisphenol-A (BPA), 7 alkylphenols (AP) and 5 phthalates (PAE) (for detailed list see Table 3).

Nutrients were analyzed in the total and dissolved phases, while OC, metals, major elements and organic micropollutants were analyzed in the particulate and dissolved phases.

Upon reception, samples were divided into aliquots for the analysis of different pollutants. Aliquots used for the analysis of TSS, OC, BPA, AP and PAE were filtered immediately; the filtrate was extracted within $24 \mathrm{~h}$, while filters were freeze-dried before extraction. Other aliquots were put on ice and sent to partner laboratories within $24 \mathrm{~h}$ of collection for the analysis of nutrients, TPH, PAH (Cerema in Trappes, France), trace and major elements (IFSTTAR in Nantes, France). These samples were filtered upon arrival at the partner laboratory.

Extraction and analytical methods are summarized in Table 3. 


\begin{tabular}{|c|c|c|c|c|}
\hline Parameter & Substances and abbreviations & Method & Limit of quantification (LQ) & Uncertainty \\
\hline $\begin{array}{l}\text { Suspended } \\
\text { solids }\end{array}$ & Total suspended solids (TSS) & $\begin{array}{l}\text { Filter : } 0.7 \mu \mathrm{m} \text { fiberglass } \\
\text { Method: Filtration } \\
\text { Standard : NF EN } 872\end{array}$ & $2 \mathrm{mg} / \mathrm{L}$ & $\begin{array}{c}\text { Confidence level (CL) : } 95 \% \\
\frac{ \pm 10}{\sqrt{3}}\end{array}$ \\
\hline $\begin{array}{l}\text { Organic } \\
\text { carbon }\end{array}$ & $\begin{array}{l}\text { Total organic carbon (TOC), } \\
\text { Dissolved organic carbon (DOC) }\end{array}$ & $\begin{array}{l}\text { Filter : } 0.7 \mu \mathrm{m} \text { fiberglass } \\
\text { Method: Thermal combustion- } \\
\text { Infrared detector } \\
\begin{array}{l}\text { Standard: NF } \\
\text { (dissolved) }\end{array}\end{array}$ & $\begin{array}{l}\text { Dissolved: } \\
0.3 \mathrm{mg} / \mathrm{L} \\
\text { Particulaire: } \\
\frac{70}{M} \mathrm{mg} / \mathrm{g}\end{array}$ & CL: $95 \%$ \\
\hline Nutrients & $\begin{array}{l}\text { Kjehldahl nitrogen }(\mathrm{KN}) \text {, } \\
\text { Ammonium }\left(\mathrm{NH}_{4}{ }^{+}\right) \text {, Nitrite }\left(\mathrm{NO}_{2}^{-}\right) \text {, } \\
\text { Nitrate }\left(\mathrm{NO}_{3}{ }^{-}\right) \text {, Phosphorus (P), } \\
\text { Phosphate }\left(\mathrm{PO}_{4}{ }^{3-}\right)\end{array}$ & 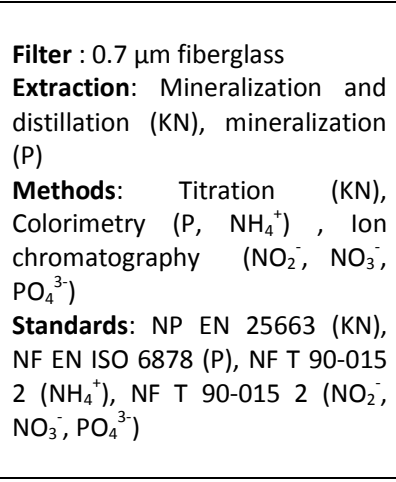 & $\begin{array}{l}\text { Dissolved and Total: } \\
1(\mathrm{KN}), 0.1(\mathrm{P}) \mathrm{mg} / \mathrm{L} \\
\text { Dissolved: } \\
0.04\left(\mathrm{~N}-\mathrm{NH}_{4}^{+}\right), 0.08\left(\mathrm{~N}-\mathrm{NO}_{2}{ }^{-}\right) \text {, } \\
0.05\left(\mathrm{~N}-\mathrm{NO}_{3}{ }^{-}\right), 0.16\left(\mathrm{P}^{-} \mathrm{PO}_{4}{ }^{3-}\right) \\
\mathrm{mg} / \mathrm{L}\end{array}$ & 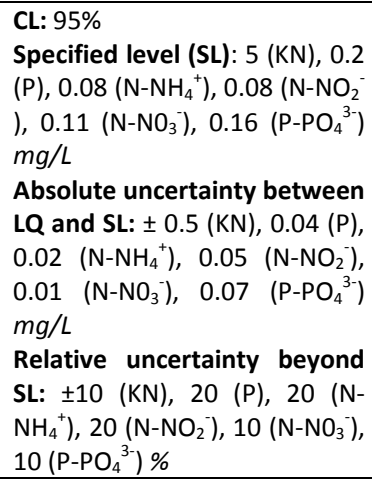 \\
\hline $\begin{array}{l}\text { Trace } \\
\text { metals } \\
\text { and } \\
\text { Major } \\
\text { elements }\end{array}$ & 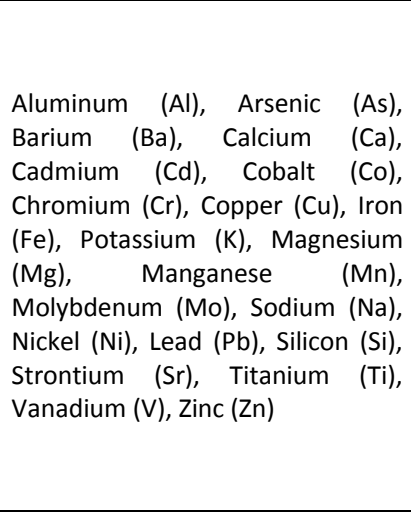 & $\begin{array}{l}\text { Filter: } 0.45 \mu \mathrm{m} \text { cellulose acetate } \\
\text { Extraction: Acidification to } 1 \% \\
\mathrm{HNO}_{3} \quad \text { (dissolved), Total } \\
\text { solubilization by } \mathrm{HF} \text { and } \mathrm{HClO}_{4} \\
\text { acid digestion, evaporation and } \\
\text { resuspension with } \mathrm{HNO}_{3} \\
\text { (particulate) } \\
\text { Methods: ICP-MS and ICP-OES } \\
\text { Standards: NF X31-147 (acid } \\
\text { digestion), NF EN ISO } 17294 \text { (ICP- } \\
\text { MS), NF EN ISO } 11885 \text { (ICP-OES) }\end{array}$ & $\begin{array}{l}\text { Dissolved: } \\
100(\mathrm{Al}), 0.1(\mathrm{As}), 5(\mathrm{Ba}), 100 \\
(\mathrm{Ca}), 0.1(\mathrm{Cd}), 2(\mathrm{Co}), 0.1(\mathrm{Cr}), \\
0.2(\mathrm{Cu}), 5(\mathrm{Fe}), 100(\mathrm{~K}), 10 \\
(\mathrm{Mg}), 1(\mathrm{Mn}), 2(\mathrm{Mo}), 100 \\
(\mathrm{Na}), 0.2(\mathrm{Ni}), 0.1(\mathrm{~Pb}), 0.06 \\
(\mathrm{Si}), 1(\mathrm{Sr}), 2(\mathrm{Ti}), 0.1(\mathrm{~V}), 0.3 \\
\text { (Zn) } \mu \mathrm{g} / \mathrm{L} \\
\text { Particulate: } 20(\mathrm{Al}), 1(\mathrm{As}), 1 \\
(\mathrm{Ba}), 20(\mathrm{Ca}), 0.1(\mathrm{Cd}), 0.4 \\
(\mathrm{Co}), 1(\mathrm{Cr}), 0.4(\mathrm{Cu}), 1(\mathrm{Fe}), \\
20(\mathrm{~K}), 2(\mathrm{Mg}), 0.2(\mathrm{Mn}), 0.4 \\
(\mathrm{Mo}), 20(\mathrm{Na}), 1(\mathrm{Ni}), 1(\mathrm{~Pb}), \\
200(\mathrm{Si}), 0.1(\mathrm{Sr}), 0.4(\mathrm{Ti}), 0.4 \\
(\mathrm{~V}), 1(\mathrm{Zn}) \mathrm{mg} / \mathrm{kg}\end{array}$ & $\begin{array}{l}\text { CL: 95\% } \\
\text { Dissolved: } \\
\pm 7(\mathrm{Al}), 9(\mathrm{As}), 9(\mathrm{Ba}), 8(\mathrm{Ca}), 8 \\
(\mathrm{Cd}), 6(\mathrm{Co}), 11(\mathrm{Cr}), 9(\mathrm{Cu}), 6 \\
(\mathrm{Fe}), 10(\mathrm{~K}), 6(\mathrm{Mg}), 7(\mathrm{Mn}), 9 \\
\text { (Mo), } 9(\mathrm{Na}), 11(\mathrm{Ni}), 9(\mathrm{~Pb}), 8 \\
(\mathrm{Sr}), 8(\mathrm{Ti}), 10(\mathrm{~V}), 14(\mathrm{Zn}) \% \\
\text { Particulate: } \pm 10(\mathrm{Al}), 11(\mathrm{As}), \\
10(\mathrm{Ba}), 9(\mathrm{Ca}), 24(\mathrm{Cd}), 14 \\
(\mathrm{Co}), 13(\mathrm{Cr}), 14(\mathrm{Cu}), 11(\mathrm{Fe}), 9 \\
(\mathrm{~K}), 10(\mathrm{Mg}), 13(\mathrm{Mn}), 23(\mathrm{Mo}), \\
9(\mathrm{Na}), 15(\mathrm{Ni}), 16(\mathrm{~Pb}), 10(\mathrm{Sr}), \\
12(\mathrm{Ti}), 13(\mathrm{~V}), 13(\mathrm{Zn}) \%\end{array}$ \\
\hline $\mathrm{TPH}$ & $\begin{array}{l}\text { Total petroleum hydrocarbons } \\
\mathrm{C}_{10}-\mathrm{C}_{40}(\mathrm{TPH})\end{array}$ & $\begin{array}{l}\text { Filter: } 0.7 \mu \mathrm{m} \text { fiberglass } \\
\text { Extraction: Liquid-liquid } \\
\text { (dissolved), ultrasound solid- } \\
\text { liquid (particulate) } \\
\text { Method: GC-FID } \\
\text { Standard: NF EN ISO } \\
\text { (dissolved), NP ISO } 16703-2 \\
\text { (particulate) }\end{array}$ & $\begin{array}{l}\text { Dissolved: } \\
0.2 \mathrm{mg} / \mathrm{L} \\
\text { Particulate: } \\
\frac{50}{M} \mathrm{mg} / \mathrm{g}\end{array}$ & $\begin{array}{l}\text { CL: } 95 \% \\
\text { SL: } 0.3 \mathrm{mg} / \mathrm{L} \text { (dissolved), } 75 \\
\mu \mathrm{g} / \mathrm{g} \text { (particulate) } \\
\text { Absolute uncertainty between } \\
\mathrm{LQ} \text { and SL: } \pm 0.12 \mathrm{mg} / \mathrm{L} \\
\text { (dissolved), } 30 \mathrm{mg} / \mathrm{kg} \\
\text { (particulate) } \\
\text { Relative uncertainty beyond } \\
\begin{array}{l}\text { SL: } \pm 40 \% \text { (dissolved and } \\
\text { particulate) }\end{array}\end{array}$ \\
\hline PAH & 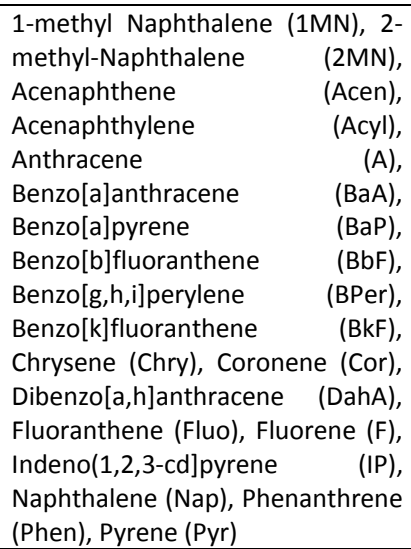 & $\begin{array}{l}\text { Filter: } 0.7 \mu \mathrm{m} \text { fiberglass } \\
\text { Extraction: Liquid-liquid } \\
\text { (dissolved), ultrasound solid- } \\
\text { liquid (particulate) } \\
\text { Method: GC-MS } \\
\text { Standard: XP ISO-TS } 28581 \text { and } \\
\text { NF ISO } 28540 \text { (dissolved), XP } \\
\text { X33-012 and NF EN 15527 } \\
\text { (particulate) }\end{array}$ & $\begin{array}{l}\text { Dissolved: } \\
10 \mathrm{ng} / \mathrm{L} \\
\text { Particulate: } \\
\frac{20}{M} \mu \mathrm{g} / \mathrm{g}\end{array}$ & $\begin{array}{l}\text { CL: } 95 \% \\
\text { SL: } 20 \mathrm{ng} / \mathrm{L} \text { (dissolved), } 0.03 \\
\mu \mathrm{g} / \mathrm{g} \text { (particulate) } \\
\text { Absolute uncertainty between } \\
\text { LQ and SL: } \pm 6 \mathrm{ng} / \mathrm{L} \text { (dissolved), } \\
0.006 \mu \mathrm{g} / \mathrm{g} \text { (particulate) } \\
\text { Relative uncertainty beyond } \\
\text { SL: } \pm 40 \text { (dissolved), } 20 \\
\text { (particulate) \% }\end{array}$ \\
\hline
\end{tabular}




\begin{tabular}{|c|c|c|c|c|}
\hline BPA/AP & 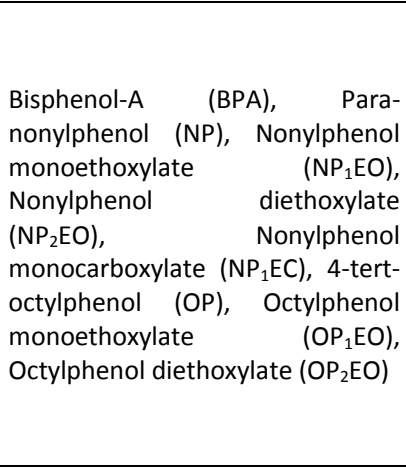 & $\begin{array}{l}\text { Filter: } 0.7 \mu \mathrm{m} \text { fiberglass } \\
\text { Extraction: } \quad \text { Solid-phase } \\
\text { (dissolved), } \quad \text { Microwave } \\
\text { (particulate) } \\
\text { Method: UPLC-MSMS }\end{array}$ & $\begin{array}{l}\text { Dissolved: } \\
11 \quad(\mathrm{BPA}), 79 \quad(\mathrm{NP}), \quad 31 \\
\left(\mathrm{NP}_{1} \mathrm{EO}\right), 62 \quad\left(\mathrm{NP}_{2} \mathrm{EO}\right), \quad 2 \\
\left(\mathrm{NP}_{1} \mathrm{EC}\right), 7(\mathrm{OP}), 17\left(\mathrm{OP}_{1} \mathrm{EO}\right), \\
5\left(\mathrm{OP}_{2} \mathrm{EO}\right) \mathrm{ng} / \mathrm{L} \\
\text { Particulate: } \\
\frac{2.6}{M} \quad(\mathrm{BPA}), \frac{20}{M} \quad(\mathrm{NP}), \frac{7.7}{M} \\
\left(\mathrm{NP}_{1} \mathrm{EO}\right), \frac{16}{M} \quad\left(\mathrm{NP}_{2} \mathrm{EO}\right), \frac{0.43}{M} \\
\left(\mathrm{NP}_{1} \mathrm{EC}\right), \frac{1.7}{M} \quad(\mathrm{OP}), \frac{4.2}{M} \\
\left(\mathrm{OP}_{1} \mathrm{EO}\right), \frac{1.3}{M}\left(\mathrm{OP}_{2} \mathrm{EO}\right) \mu \mathrm{g} / \mathrm{g}\end{array}$ & $\begin{array}{l}\text { CL: } 80 \% \\
\text { Dissolved : } \pm 28(\mathrm{BPA}), 37(\mathrm{NP}), \\
91\left(\mathrm{NP} \mathrm{P}_{1} \mathrm{EO}\right), 67\left(\mathrm{NP}_{2} \mathrm{EO}\right), 29 \\
\left(\mathrm{NP}_{1} \mathrm{EC}\right), 61(\mathrm{OP}), 25\left(\mathrm{OP}_{1} \mathrm{EO}\right), \\
32\left(\mathrm{OP}{ }_{2} \mathrm{EO}\right) \% \\
\text { Particulate: } \pm 25(\mathrm{BPA}), 44 \\
(\mathrm{NP}), 43\left(\mathrm{NP} \mathrm{E}_{1} \mathrm{EO}\right), 56\left(\mathrm{NP} \mathrm{P}_{2} \mathrm{EO}\right), \\
49\left(\mathrm{NP} \mathrm{P}_{1} \mathrm{EC}\right), 48(\mathrm{OP}), 40 \\
\left(\mathrm{OP}_{1} \mathrm{EO}\right), 19\left(\mathrm{OP}_{2} \mathrm{EO}\right) \%\end{array}$ \\
\hline PAE & $\begin{array}{l}\text { Dimethyl phthalate (DMP), } \\
\text { Diisobutyl phthalate (DiBP), } \\
\text { Dibutyl phthalate (DBP), Bis(2- } \\
\text { ethylhexyl) phthalate (DEHP), } \\
\text { Dinonyl phthalate (DNP) }\end{array}$ & $\begin{array}{l}\text { Filter: } 0.7 \mu \mathrm{m} \text { fiberglass } \\
\text { Extraction: } \quad \text { Solid-phase } \\
\text { (dissolved), } \\
\text { (particulate) } \\
\text { Method: GC-MS }\end{array}$ & 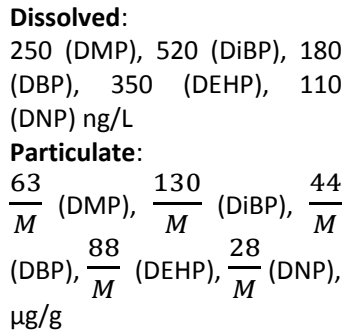 & $\begin{array}{l}\text { CL: } 80 \% \\
\text { Dissolved : } \pm 55 \text { (DMP), } 63 \\
\text { (DiBP), } 24 \text { (DBP), } 53 \text { (DEHP), } 32 \\
\text { (DNP) \% } \\
\text { Particulate: } \pm 45 \text { (DMP), } 35 \\
\text { (DiBP), } 25 \text { (DBP), } 35 \text { (DEHP), } 50 \\
\text { (DNP) \% }\end{array}$ \\
\hline
\end{tabular}

Table 3: Summary of employed analytical methods. $\mathrm{M}$ is the mass of TSS extracted in $\mathrm{mg}$, which varied according to the concentration of TSS in the water sample and the filtered volume. Abbreviations: ICP-OES (inductively coupled plasma optical emission spectroscopy), ICP-MS (inductively coupled plasma mass spectrometry), GC-MS (gas chromatography coupled with mass spectrometry), UPLC-MSMS (ultra performance liquid chromatography with tandem mass spectrometry); GC-FID (gas chromatography - flame ionization detector)

\subsection{Calculation of performance indicators, uncertainty propagation and statistical methods}

All statistical calculations were carried out using the software environment, $R$.

The significance of differences between inlet and outlet concentrations, taking into account interevent variability was evaluated using the Wilcoxon Signed-Rank Test, a non-parametric, paired test. Correlations between parameters were tested using the Spearman Rank Correlation Test, also a nonparametric method.

The studied biofiltration devices, installed to treat water from a catchment expected to generate highly polluted runoff, were designed with a specific objective of improving water quality to protect the quality of groundwater. Therefore, its efficiency at achieving this objective was evaluated according to concentration reduction $\left(E_{c}\right)$, which was calculated according to Equation 1 for events for which (1) both RR and the outlet were sampled and (2) RR and/or the outlet concentrations were superior to the limit of quantification (LQ). When one of the concentrations was below the LQ, it was set equal to the $L Q$, making the $E_{c}$ a lower bound if the pollutant was below the $L Q$ at the outlet and an upper bound if it was below the LQ only at the inlet.

$E_{c}=\frac{C_{R R}-C_{\text {outlet }}}{C_{R R}} \cdot 100$

where $E_{c}$ is the event concentration reduction efficiency in \%, $C_{R R}$ is the road runoff concentration and $\mathrm{C}_{\text {outlet }}$ is the BFS or VFS concentration.

As analytical uncertainties were sometimes large, especially for organic micropollutants, the analytical significance of each calculated $E_{c}$ was considered. $E_{c}$ was considered to be analytically significant if its efficiency was greater than the uncertainty in $E_{c}$, propagated from the concentrations used in its calculation according to the rules of uncertainty propagation (Taylor, 1997), assuming their errors to be independent. Uncertainty calculations are further detailed in Supplementary 
Information. Results were summarized with the indicator $F_{\text {sig, }}$ the fraction of events with a significant concentration reduction, calculated for each pollutant.

Concentration probability distributions at each point were visualized using a logarithmic scale on the concentration axis, according to the recommendations of GeoSyntec Consultants et al. (2002).

\section{Results}

\subsection{Characterization of road runoff}

The characteristics of the untreated road runoff (RR) are summarized in Tables 4-7 and described below. Results for TSS, organic carbon, trace metals and organic micropollutants are described below while those for other global parameters ( $\mathrm{pH}, \mathrm{EC}$, nutrients) are presented in Supplementary Information.

\section{Global Parameters}

TSS concentrations (median $291 \mathrm{mg} / \mathrm{L}$, Table 4) always exceeded the national objective concentration of $50 \mathrm{mg} / \mathrm{L}$ for surface waters (MEEM, 2016) and were higher than most chronic contamination concentrations from the scientific literature (Helmreich et al., 2010; Kayhanian et al., 2012; Lundy et al., 2012). These higher concentrations may be due to a high production of wear particles at this site compared to traffic due to its location in an acceleration zone following a roundabout and a relatively high proportion of heavy trucks, both factors associated with higher production of wear particles (US EPA, 2014). Another factor may be the relatively low rainfall over the period studied $(917 \mathrm{~mm}$ of rainfall over about 1.5 years), leading to more concentrated runoff than at sites with higher rainfall.

TOC concentrations (median $49 \mathrm{mg} / \mathrm{L}$ ) were also found to be on the high end of those previously reported. Although DOC (median $6.1 \mathrm{mg} / \mathrm{L}$ ) frequently exceeded the objective concentration of 5 $\mathrm{mg} / \mathrm{L}$ (MEEM, 2016), organic carbon was mainly particulate, a notable difference from previous studies with higher DOC concentrations, which found organic carbon in road runoff to be mainly dissolved (Kayhanian et al., 2012). The sorption of organic carbon to the relatively plentiful TSS particles is likely responsible for this disparate partitioning.

\section{Trace Metals}

Total trace metal concentrations (Table 5) fell within the range of concentrations found in the scientific literature (Huber et al., 2016; Kayhanian et al., 2012; Lundy et al., 2012). Pb and Zn median concentrations ( 62.9 and $693 \mu \mathrm{g} / \mathrm{L}$, respectively) were found to be above the $90^{\text {th }}$ percentile of recently measured concentrations, while $\mathrm{Cu}$ concentrations were among the highest previously observed (median $258 \mu \mathrm{g} / \mathrm{L}$ ).

All trace metals were mainly associated with the particulate phase. $\mathrm{Cu}, \mathrm{Pb}$ and $\mathrm{Zn}$ were all found to be more particulate in this study (median 92, 99, 95\%, respectively) than in most previous studies from similar highway surfaces, for which median particulate fractions were found to be 62,96 and $69 \%$ (Huber et al., 2016). Particle concentrations of both $\mathrm{Cu}$ and $\mathrm{Zn}$ (median 628 and $1790 \mu \mathrm{g} / \mathrm{g}$, respectively) were high compared to previously reported road debris concentrations (Brown and Peake, 2006), while dissolved concentrations were normal or low ( 25 and $32 \mu \mathrm{g} / \mathrm{L}$ ) compared to those in the literature (Huber et al., 2016); the production of high levels of particulate metals at this site therefore appears to be responsible for this partitioning, rather than sorption of dissolved pollutants to the relatively abundant TSS. Another explanation may be the total mineralization of the solid phase used in this study, while for many road runoff studies the particulate phase is obtained by difference between $\mathrm{HNO}_{3} / \mathrm{HCl}$ extraction of total and dissolved samples. Both $\mathrm{Cu}$ and $\mathrm{Zn}$ systematically exceeded environmental quality standards (EQS) applicable in France for dissolved 
trace metal concentrations, while As surpassed its EQS for about half of the rain events and $\mathrm{Cd}, \mathrm{Cr}, \mathrm{Ni}$ and $\mathrm{Pb}$ were always below the EQS.

Total petroleum hydrocarbon and polycyclic aromatic hydrocarbons

Total petroleum hydrocarbon (TPH) concentrations ranged from 0.29 to $3.96 \mathrm{mg} / \mathrm{L}$ with a median of $1.12 \mathrm{mg} / \mathrm{L}$ for the total concentration (Table 6). This concentration is similar to medians observed in previous studies of road runoff (Kayhanian et al., 2007). This parameter was never quantified in the dissolved phase.

The sum of the 16 US EPA priority PAH varied from $1.3 \mu \mathrm{g} / \mathrm{L}$ to $11.5 \mu \mathrm{g} / \mathrm{L}$ with a median concentration of $4.9 \mu \mathrm{g} / \mathrm{L}$, within the range predicted for major roads by Lundy et al. (2012). Compared to recent studies in France, this is higher than concentrations measured in runoff from an industrial and two residential urban catchments (Gasperi et al., 2014) and lower than those observed from a roadway in a commercial sector with lower traffic (Leroy et al., 2016). The PAH fingerprint and possible sources of these pollutants are discussed in Supplementary Information.

Only three PAH were quantified in the dissolved phase for all events: Phen, Fluo and Pyr, and even these species were found to be predominantly particulate (median 93, 98 and 99\%, respectively). By contrast, Nielsen et al. (2015) quantified the majority of PAH in stormwater from a mixed urban catchment in the dissolved phase and observed an average particulate ratio of only $82 \%$, a difference possibly explained by lower TSS concentrations (median $31 \mathrm{mg} / \mathrm{L}$ for samples analyzed for PAH) than in the present study.

Among the PAH molecules considered priority pollutants in the European Union Water Framework Directive (EC, 2013), only Nap was always below the annual mean EQS; respective EQS were often surpassed by $A$ and systematically exceeded for Fluo and BaP.

Bisphenol-A and Alkylphenols

Observed BPA concentrations (median $412 \mathrm{ng} / \mathrm{L}$, Table 7) were on the order of those previously measured in urban runoff in France (Gasperi et al., 2014; Sebastian, 2013) and in the lower range of those observed in road runoff (Stachel et al., 2010).

Among alkylphenols, 4-NP was found at the highest concentrations (median $1647 \mu \mathrm{g} / \mathrm{L}$ ), followed by $\mathrm{OP}, \mathrm{NP}_{1} \mathrm{EO}, \mathrm{NP}_{2} \mathrm{EO}, \mathrm{NP}_{1} \mathrm{EC}$, and $\mathrm{OP}_{2} \mathrm{EO}\left(430,366,220,113\right.$, and $29 \mathrm{ng} / \mathrm{L}$, respectively). OP ${ }_{1} \mathrm{EO}$, only quantified in $42 \%$ of RR samples, was the least abundant molecule in the family. NP and OP were similar to previously reported concentrations in road runoff (Bressy, 2010; Stachel et al., 2010) and distinctly higher than those resulting from the study of runoff from mixed urban catchments (Bressy et al., 2012; Gasperi et al., 2014; Sebastian, 2013; Zgheib et al., 2012). The ranks of molecules within the NP and OP families concord with those observed in mixed urban runoff (Gasperi et al., 2014; Sebastian, 2013), with the exception of $\mathrm{NP}_{1} \mathrm{EC}$, which had a higher rank in previous studies than in the present study. Both NP and OP concentrations systematically exceeded the EQS.

Besides $\mathrm{OP}_{1} \mathrm{EO}$ and $\mathrm{OP}_{2} \mathrm{EO}$, which were rarely quantified in the dissolved phase, most molecules of this family were quantified in both dissolved and particulate phase. They were also found to be less strongly associated with the particulate phase than the trace metals and $\mathrm{PAH}$ with median particulate proportions of $28,73,67,72,33$, and $5 \%$ for $B P A, N P, O P, N P_{1} E O, N_{2} E O$ and $N_{1} E C$, respectively.

Phthalates

Phthalate concentrations were on the same order of magnitude as other urban and road runoff concentrations from the scientific literature. For example, the median DEHP concentration in RR was 
$14 \mu \mathrm{g} / \mathrm{L}$ compared to concentrations between 0.1-24 $\mu \mathrm{g} / \mathrm{L}$ (Clara et al., 2010), $<1$ to $5 \mu \mathrm{g} / \mathrm{L}$ (Björklund et al., 2009) and 3-58 $\mathrm{mg} / \mathrm{L}$ (Zgheib et al., 2012). Similarly, the relative abundance of molecules (DEHP>DiBP $>$ DBP $>$ DMP $>$ DNP) corroborated the previous observations of DEHP>DMP (Björklund et al., 2009) and DEHP>DBP>DMP (Clara et al., 2010). The EQS concentration of $1.3 \mu \mathrm{g} / \mathrm{L}$ for DEHP was exceeded for all events.

DMP, DiBP, DBP, DEHP, DNP were quantified in $45,85,100,100,8 \%$ of samples in the dissolved phase and $33,100,100,100$ and $50 \%$ of samples in the particulate phase, respectively. Phthalates were found to be moderately to highly particulate depending on the compound $(27,56,40,72$ and $92 \%$ for DMP, DiBP, DBP, DEHP, DNP) with the highest particulate ratios corresponding to those molecules with the highest molecular weight. 


\begin{tabular}{|c|c|c|c|c|c|c|c|c|c|c|c|c|c|c|}
\hline & \multirow{2}{*}{ Parameter } & \multicolumn{6}{|c|}{ Total Phase } & \multicolumn{6}{|c|}{ Dissolved Phase } & \multirow{2}{*}{$\begin{array}{c}\text { Water } \\
\text { Quality } \\
\text { Objective }\end{array}$} \\
\hline & & RR & $n$ & VFS & $n$ & BFS & $n$ & RR & $n$ & VFS & $n$ & BFS & $n$ & \\
\hline & $\begin{array}{l}\text { Conductivity } \\
(\mu \mathrm{S} / \mathrm{cm})\end{array}$ & $234(88,1950)$ & 14 & $437(188,6585)^{\circ}$ & 18 & $467(250,5365)^{\circ}$ & 15 & \multirow{2}{*}{\multicolumn{6}{|c|}{-}} & - \\
\hline & Turbidity & $291(60,>1000)$ & 14 & $30(6,324)^{*}$ & 18 & $37(12,878)^{*}$ & 15 & & & & & & & - \\
\hline & TSS (mg/L) & $291(70,933)$ & 14 & $18(2.9,154)^{*}$ & 18 & $18(8.7,520)^{*}$ & 15 & - & 50 & & & & & \\
\hline & $\mathrm{OC}(\mathrm{mg} / \mathrm{L})$ & $49(14,111)$ & 13 & $14(3.8,31)^{*}$ & 16 & $15(4.6,82)^{*}$ & 13 & $6.1(1.7,14.7)$ & 14 & $10.5(3.2,23.9)^{\circ}$ & 18 & $9.8(3.3,16.1)^{\circ 0}$ & 15 & $5^{D}$ \\
\hline \multirow{6}{*}{$\begin{array}{l}\frac{n}{4} \\
\frac{d}{2} \\
\frac{2}{2} \\
z \\
z\end{array}$} & $\mathrm{KN}(\mathrm{mg} / \mathrm{L}-\mathrm{N})$ & $2.92(<1,5.58)$ & 13 & $1.07(<1,5.03)^{*}$ & 16 & $1.63(<1,3.93)^{*}$ & & $<1(<1,1.33)$ & 13 & $<1(<1,1.79)$ & 16 & $<1(<1,2.02)$ & 13 & - \\
\hline & \begin{tabular}{|lll}
$\mathrm{NH}_{4}^{+}$ & $(\mathrm{mg} / \mathrm{L}$ & - \\
$\mathrm{N})$ &
\end{tabular} & \multirow{3}{*}{\multicolumn{6}{|c|}{-}} & $0.20(<0.04,0.48)$ & 13 & $<0.04(<0.04,0.32)^{* *}$ & 16 & $0.06(<0.04,0.29)^{* *}$ & 13 & 0.4 \\
\hline & $\mathrm{NO}_{3}^{-}(\mathrm{mg} / \mathrm{L}-\mathrm{N})$ & & & & & & & $0.47(<0.05,1.84)$ & 13 & $0.40(<0.05,1.94)$ & 16 & $0.85(<0.05,2.16)$ & 13 & 11 \\
\hline & $\mathrm{NO}_{2}^{-}(\mathrm{mg} / \mathrm{L}-\mathrm{N})$ & & & & & & & $<0.08(<0.08,0.27)$ & 13 & $<0.08(<0.08,0.24)$ & 13 & $0.08(<0.08,0.20)$ & 13 & 0.09 \\
\hline & $P(m g / L-P)$ & $0.48(0.13,2.05)$ & 13 & $0.18(<0.1,0.65)^{* *}$ & 16 & $0.25(<0.1,0.89)^{* *}$ & 13 & $<0.1(<0.1,0.14)$ & 13 & $0.11(<0.1,0.20)^{\circ \circ}$ & 16 & $0.13(<0.1,0.22)$ & 13 & 0.2 \\
\hline & $\begin{array}{ll}\mathrm{PO}_{4}{ }^{3-} \quad(\mathrm{mg} / \mathrm{L} & - \\
\mathrm{P})\end{array}$ & & & - & & & & $<0.16$ & 13 & $<0.16$ & 16 & $<0.16$ & 13 & 0.16 \\
\hline \multirow{9}{*}{ 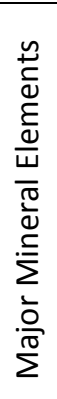 } & $\mathrm{Al}(\mathrm{mg} / \mathrm{L})$ & $14.4(3.8,34.6)$ & 12 & $1.0(0.1,6.5)^{*}$ & 16 & $1.5(0.3,24.6)^{*}$ & 14 & $<0.1(<0.1,0.12)$ & 11 & $<0.1(<0.1,0.23)$ & 15 & $<0.1(<0.1,0.24)$ & 13 & - \\
\hline & $\mathrm{Fe}(\mathrm{mg} / \mathrm{L})$ & $13.8(3.9,32.7)$ & 12 & $0.9(0.1,5.6)^{*}$ & 16 & $1.2(0.2,21.7)^{*}$ & 14 & $0.06(0.03,0.10)$ & 11 & $0.07(0.01,0.19)$ & 15 & $0.05(0.01,0.23)$ & 13 & - \\
\hline & $\mathrm{Mn}(\mathrm{mg} / \mathrm{L})$ & $0.26(0.06,0.61)$ & 12 & $0.014(0.003,0.089)^{*}$ & 16 & $0.02(0.01,0.34)^{*}$ & 14 & $0.003(0.001,0.016)$ & 11 & $0.003(<0.001,0.015)^{* *}$ & 15 & $0.002(<0.001,0.050)$ & 13 & - \\
\hline & $\mathrm{Ti}(\mathrm{mg} / \mathrm{L})$ & $0.82(0.21,2.01)$ & 12 & $0.05(0.01,0.31)^{*}$ & 16 & $0.07(0.02,1.30)^{*}$ & 14 & $0.002(<0.002,0.004)$ & 11 & $0.004(<0.002,0.008)$ & 15 & $0.004(<0.002,0.019)$ & 13 & - \\
\hline & $\mathrm{Na}(\mathrm{mg} / \mathrm{L})$ & $30.2(10.3,377.5)$ & 12 & $46.6(7.7,1355.8)^{\circ}$ & 16 & $45.0(9.3,891.4)^{\circ}$ & 14 & $30.5(6.5,374.0)$ & 11 & $48.8(7.7,1353.3)^{\circ}$ & 15 & $38.4(9.3,886.9)^{\circ}$ & 13 & - \\
\hline & $\mathrm{K}(\mathrm{mg} / \mathrm{L})$ & $4.73(2.34,11.67)$ & 12 & $2.12(0.42,7.91)^{*}$ & 16 & $3.76(2.14,13.77)$ & 14 & $1.22(0.68,4.01)$ & 11 & $1.54(0.32,6.55)^{*}$ & 15 & $3.00(2.03,7.89)^{\circ}$ & 13 & - \\
\hline & $\mathrm{Mg}(\mathrm{mg} / \mathrm{L})$ & $5.20(1.68,11.97)$ & 12 & $2.10(1.18,6.59)^{*}$ & 16 & $2.93(1.40,15.54)$ & 14 & $0.68(0.33,1.07)$ & 11 & $1.60(0.91,5.20)^{\circ}$ & 15 & $2.58(1.33,9.36)^{\circ}$ & 13 & - \\
\hline & $\mathrm{Ca}(\mathrm{mg} / \mathrm{L})$ & $61.0(21.3,145.2)$ & 12 & $40.4(22.4,154.5)$ & 16 & $57.5(32.2,248.9)$ & 14 & $17.6(11.8,23.9)$ & 11 & $36.7(21.6,144.5)^{\circ}$ & 15 & $52.6(29.3,197.6)^{\circ}$ & 13 & - \\
\hline & $\mathrm{Si}(\mathrm{mg} / \mathrm{L})$ & \multicolumn{5}{|c|}{-} & 13 & $1.27(0.76,18.70)$ & 10 & $2.60(0.84,3.67)$ & 14 & $3.54(2.58,5.08)^{\circ \circ}$ & 12 & - \\
\hline
\end{tabular}

Table 4: Median (minimum, maximum) values observed for total and dissolved phase global parameters in untreated road runoff (RR), drained water from the vegetative filter strip (VFS) and drained water from the biofiltration swale (BFS), compared to French objectives for good quality surface water (MEEM, 2016). Outlet (VFS or BFS) values significantly lower than those in RR represented by $*(P<0.01)$ or $* *(P<0.05)$; significantly higher by ${ }^{\circ}(P<0.01)$ or ${ }^{\circ}(P<0.05)$. 


\begin{tabular}{|c|c|c|c|c|c|c|c|}
\hline \multirow{2}{*}{ Trace Metals } & \multicolumn{3}{|c|}{ Total Concentrations } & \multicolumn{3}{|c|}{ Dissolved Concentrations } & \multirow{2}{*}{$\begin{array}{c}\text { EQS } \\
\text { (dissolved } \\
\text { phase) } \\
\end{array}$} \\
\hline & $\begin{array}{c}R R \\
n=12\end{array}$ & $\begin{array}{c}\text { VFS } \\
n=16\end{array}$ & $\begin{array}{c}\text { BFS } \\
n=14\end{array}$ & $\begin{array}{c}R R \\
n=11\end{array}$ & $\begin{array}{c}\text { VFS } \\
n=15\end{array}$ & $\begin{array}{c}\text { BFS } \\
n=13\end{array}$ & \\
\hline As $(\mu \mathrm{g} / \mathrm{L})$ & $4.99(2.13,12.11)$ & $1.26(0.39,4.72)^{*}$ & $3.16(1.81,11.02)^{* *}$ & $0.79(0.57,1.41)$ & $0.88(0.39,2.91)$ & $2.23(1.33,3.39)^{\circ 0}$ & $0.83^{\Delta}$ \\
\hline $\mathrm{Ba}(\mu \mathrm{g} / \mathrm{L})$ & $170(60,430)$ & $40(20,250)^{*}$ & $50(30,440)$ & $13(9,30)$ & $25(15,184)^{\circ}$ & $41(25,188)^{\circ}$ & - \\
\hline $\mathrm{Cd}(\mu \mathrm{g} / \mathrm{L})$ & $0.30(0.11,0.72)$ & $<0.1(<0.1,0.14)^{*}$ & $0.11(<0.1,0.48)^{*}$ & $<0.1$ & $<0.1$ & $<0.1$ & $0.15^{\Delta \Delta, \Delta \Delta \Delta}$ \\
\hline Co $(\mu \mathrm{g} / \mathrm{L})$ & $4.93(<2,12.20)$ & $<2 *$ & $<2(<2,7.3)^{*}$ & $<2$ & $<2$ & $<2$ & - \\
\hline $\mathrm{Cr}(\mu \mathrm{g} / \mathrm{L})$ & $37.2(12.3,83.3)$ & $3.2(0.9,15.8)^{*}$ & $5.5(2.2,57.7)^{*}$ & $0.63(<0.1,1.83)$ & $0.82(0.28,1.90)$ & $1.38(0.64,2.70)^{\circ 0}$ & $3.4^{\Delta}$ \\
\hline $\mathrm{Cu}(\mu \mathrm{g} / \mathrm{L})$ & $258(98,546)$ & $39(11,114)^{*}$ & $35(9,280)^{*}$ & $24.9(13.5,42.2)$ & $28.9(9.1,71.2)$ & $24.5(6.8,43.6)$ & $1^{\Delta}$ \\
\hline Mo $(\mu \mathrm{g} / \mathrm{L})$ & $9(2,62)$ & $4(2,35)^{* *}$ & $4(2,36)^{*}$ & $<2(<2,36)$ & $4(<2,12)$ & $4(<2,36)$ & - \\
\hline $\mathrm{Ni}(\mu \mathrm{g} / \mathrm{L})$ & $16.2(1.9,38.9)$ & $2.7(1.0,8.1)^{*}$ & $2.7(0.9,26.0)^{*}$ & $0.90(0.57,1.45)$ & $0.97(0.60,7.81)$ & $1.31(0.54,2.48)$ & $4^{\Delta \Delta}$ \\
\hline $\mathrm{Pb}(\mu \mathrm{g} / \mathrm{L})$ & $62.9(15.8,139.2)$ & $4.1(1.2,22.1)^{*}$ & $4.2(1.4,100.8)^{*}$ & $0.43(0.19,0.90)$ & $0.48(0.26,1.61)$ & $0.38(0.18,1.08)$ & $1.2^{\Delta \Delta}$ \\
\hline $\operatorname{Sr}(\mu \mathrm{g} / \mathrm{L})$ & $170(80,330)$ & $140(80,660)$ & $270(120,1020)$ & $100(57,117)$ & $133(76,631)^{\circ}$ & $261(110,907)^{\circ}$ & - \\
\hline $\mathrm{V}(\mu \mathrm{g} / \mathrm{L})$ & $27.1(11.2,70.4)$ & $3.4(1.0,12.9)^{*}$ & $9.3(4.3,54.6)^{*}$ & $1.83(1.00,3.16)$ & $1.47(0.84,0.304)$ & $4.45(1.08,10.35)^{\circ 0}$ & - \\
\hline $\mathrm{Zn}(\mu \mathrm{g} / \mathrm{L})$ & $693(236,1653)$ & $64(11,325)^{*}$ & $53(9,1057)^{*}$ & $32.3(16.0,65.9)$ & $27.7(7.5,127.0)$ & $16.4(2.9,54.1)$ & $7.8^{\Delta}$ \\
\hline
\end{tabular}

Table 5: Median (minimum, maximum) total and dissolved concentrations in road runoff (RR), the vegetative filter strip (VFS) and the biofiltration swale (BFS), compared to ${ }^{\Delta}$ French (MEEM, 2016) or ${ }^{\Delta \Delta}$ European (EC, 2013) annual mean environmental quality standards (EQS), ${ }^{\Delta \Delta \Delta}$ concentrations for Class 4 water hardness. Significant concentration reductions at BFS or VFS outlets compared to RR represented by $*(P<0.01)$ or $* *(P<0.05)$; increases by ${ }^{\circ}(P<0.01)$ or ${ }^{\circ}(\mathrm{P}<0.05)$. 


\begin{tabular}{|c|c|c|c|c|c|c|c|c|c|}
\hline & \multirow{2}{*}{ Parameter } & \multirow{2}{*}{$\log K_{\text {ow }}$} & \multicolumn{3}{|c|}{ Total Concentrations } & \multicolumn{3}{|c|}{ Dissolved Concentrations } & \multirow{2}{*}{$\begin{array}{c}\text { EQS } \\
\text { (total } \\
\text { phase }\end{array}$} \\
\hline & & & $\begin{array}{c}\mathrm{RR} \\
\mathrm{n}=12\end{array}$ & $\begin{array}{c}\text { VFS } \\
n=13\end{array}$ & $\begin{array}{c}\text { BFS } \\
n=13\end{array}$ & $\begin{array}{c}\mathrm{RR} \\
\mathrm{n}=12\end{array}$ & $\begin{array}{c}\text { VFS } \\
n=14\end{array}$ & $\begin{array}{c}\text { BFS } \\
n=13\end{array}$ & \\
\hline & $\mathrm{TPH}(\mathrm{mg} / \mathrm{L})$ & - & $1.12(0.29,3.96)$ & $0.27(0.22,0.83)^{*}$ & $0.27(0.23,1.04)^{*}$ & $<0.2$ & $<0.2$ & $<0.2$ & - \\
\hline \multirow{20}{*}{ 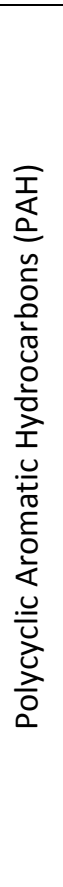 } & $\operatorname{Nap}(\mathrm{ng} / \mathrm{L})$ & 3.37 & $91(21,485)$ & $17(12,46)^{*}$ & $17(12,425)$ & $<10(<10,27)$ & $<10(<10,26)$ & $<10(<10,422)$ & 2000 \\
\hline & $1 \mathrm{MN}(\mathrm{ng} / \mathrm{L})$ & 3.87 & $29(13,54)$ & $13(11,19)^{*}$ & $14(11,253)$ & $<10(<10,12)$ & $<10$ & $<10(<10,250)$ & - \\
\hline & $2 \mathrm{MN}(\mathrm{ng} / \mathrm{L})$ & 3.94 & $50(16,119)$ & $14(12,36)^{*}$ & $15(12,203)$ & $<10(<10,17)$ & $<10$ & $<10(<10,200)$ & - \\
\hline & Acyl (ng/L) & 4.03 & $104(33,286)$ & $16(12,54)^{*}$ & $17(12,118)^{*}$ & $<10$ & $<10$ & $<10$ & - \\
\hline & Acen (ng/L) & 3.92 & $27(13,45)$ & $13(11,19)^{*}$ & $16(11,78)$ & $<10$ & $<10$ & $<10(<10,76)^{\circ \circ}$ & - \\
\hline & $\mathrm{F}(\mathrm{ng} / \mathrm{L})$ & 4.18 & $32(14,58)$ & $13(11,22)^{*}$ & $13(11,40)^{*}$ & $<10(<10,24)$ & $<10(<10,18)$ & $<10(<10,28)$ & - \\
\hline & $\mathrm{A}(\mathrm{ng} / \mathrm{L})$ & 4.50 & $130(31,337)$ & $15(12,49)^{*}$ & $17(12,118)^{*}$ & $<10$ & $<10$ & $<10$ & 100 \\
\hline & Phen (ng/L) & 4.52 & $356(102,594)$ & $28(13,107)^{*}$ & $29(12,302)^{*}$ & $23(11,100)$ & $<10(<10,56)^{*}$ & $<10(<10,98)^{*}$ & - \\
\hline & Fluo (ng/L) & 5.16 & $803(180,1601)$ & $29(13,124)^{*}$ & $47(19,462)^{*}$ & $15(13,32)$ & $<10(<10,21)^{*}$ & $15(<10,51)$ & 6.3 \\
\hline & Pyr (ng/L) & 4.97 & $851(205,2298)$ & $32(13,162)^{*}$ & $54(22,591)^{*}$ & $21(15,41)$ & $<10(<10,30)^{*}$ & $21(<10,43)$ & - \\
\hline & $\mathrm{BaA}(\mathrm{ng} / \mathrm{L})$ & 5.71 & $255(78,611)$ & $20(12,88)^{*}$ & $22(13,284)^{*}$ & $<10$ & $<10$ & $<10$ & - \\
\hline & Chry (ng/L) & 5.79 & $479(111,895)$ & $28(13,108)^{*}$ & $35(13,365)^{*}$ & $<10$ & $<10$ & $<10$ & - \\
\hline & $\mathrm{BaP}$ (ng/L) & 6.13 & $224(79,698)$ & $21(13,122)^{*}$ & $23(13,378)^{*}$ & $<10$ & $<10$ & $<10$ & 0.17 \\
\hline & $\mathrm{BkF}(\mathrm{ng} / \mathrm{L})$ & 6.35 & $179(59,485)$ & $19(12,83)^{*}$ & $22(12,222)^{*}$ & $<10$ & $<10$ & $<10$ & - \\
\hline & BPer (ng/L) & 6.77 & $361(105,966)$ & $32(13,182)^{*}$ & $35(13,506)^{*}$ & $<10$ & $<10$ & $<10$ & - \\
\hline & IP (ng/L) & 7.66 & $272(67,764)$ & $23(13,112)^{*}$ & $26(13,274)^{*}$ & $<10$ & $<10$ & $<10$ & - \\
\hline & $\mathrm{BbF}(\mathrm{ng} / \mathrm{L})$ & 6.42 & $570(159,1627)$ & $39(13,246)^{*}$ & $51(16,738)^{*}$ & $<10$ & $<10$ & $<10$ & - \\
\hline & DahA (ng/L) & 6.60 & $83(35,192)$ & $14(12,53)^{*}$ & $17(12,128)^{*}$ & $<10$ & $<10$ & $<10$ & - \\
\hline & Cor (ng/L) & 7.17 & $187(50,501)$ & $20(12,108)^{*}$ & $18(12,249)^{*}$ & $<10$ & $<10$ & $<10$ & - \\
\hline & $\Sigma_{16} \mathrm{PAH}(\mathrm{ng} / \mathrm{L})$ & - & $4907(1341,11495)$ & $409(213,1551)^{*}$ & $456(281,5047)^{*}$ & $<190(<170,<322)$ & $<160(<160,261)$ & $<160(<179,685)$ & - \\
\hline
\end{tabular}

Table 6: Median (minimum, maximum) TPH and PAH total and dissolved concentrations in road runoff (RR), vegetative filter strip (VFS) and the biofiltration swale (BFS), compared to European (EC, 2013) annual mean environmental quality standards. Octanol-water partition coefficient (log Kow), median (Mackay, 2006). Significant concentration reductions at BFS or VFS outlets compared to RR represented by $*(P<0.01)$ or $* *(P<0.05)$; increases by ${ }^{\circ}(P<0.01)$ or ${ }^{\circ}(P<0.05)$. 


\begin{tabular}{|c|c|c|c|c|c|c|c|c|c|}
\hline \multirow{2}{*}{\multicolumn{2}{|c|}{ Parameter }} & \multirow{3}{*}{$\begin{array}{c}\log K_{\mathrm{ow}} \\
3.32^{\mathrm{a}}\end{array}$} & \multicolumn{3}{|c|}{ Total Concentrations } & \multicolumn{3}{|c|}{ Dissolved Concentrations } & \multirow[b]{2}{*}{$\begin{array}{c}\text { EQS } \\
\text { (total } \\
\text { phase) }\end{array}$} \\
\hline & & & $\begin{array}{c}\text { RR } \\
n=12\end{array}$ & $\begin{array}{c}\text { VFS } \\
n=15 \text { (BPA, AP) } \\
n=13 \text { (PAE) } \\
\end{array}$ & $\begin{array}{c}\text { BFS } \\
n=12 \text { (BPA, AP) } \\
n=11 \text { (PAE) } \\
\end{array}$ & $\begin{array}{c}R R \\
n=13\end{array}$ & $\begin{array}{c}\text { VFS } \\
n=15 \text { (BPA, AP) } \\
n=14 \text { (PAE) } \\
\end{array}$ & $\begin{array}{c}\text { BFS } \\
n=13 \text { (BPA, AP) } \\
n=11 \text { (PAE) }\end{array}$ & \\
\hline & BPA (ng/L) & & $412(234,964)$ & $83(18,151)^{*}$ & $195(132,549)^{* *}$ & $280(66,697)^{*}$ & $76(18,148)$ & $165(110,510)$ & - \\
\hline \multirow{7}{*}{$\begin{array}{l}\frac{n}{0} \\
\frac{1}{0} \\
\frac{c}{0} \\
\frac{2}{2} \\
\frac{1}{2}\end{array}$} & OP (ng/L) & $3.91^{\mathrm{b}}$ & $430(235,1527)$ & $37(17,155)^{*}$ & $79(35,1762)$ & $126(33,224)^{*}$ & $29(9,123)$ & $38(13,161)^{* *}$ & 100 \\
\hline & $\mathrm{OP}_{1} \mathrm{EO}(\mathrm{ng} / \mathrm{L})$ & $4.59^{c}$ & $26(22,298)$ & $19(17,50)^{* *}$ & $23(19,90)$ & $<17(<17,291)$ & $<17(<17,47)$ & $<17(<17,85)$ & - \\
\hline & $\mathrm{OP}_{2} \mathrm{EO}(\mathrm{ng} / \mathrm{L})$ & $4.51^{\mathrm{c}}$ & $29(7,56)$ & $7(<6,13)^{*}$ & $8(6,37)$ & $<6(<6,22)$ & $<6$ & $<6$ & - \\
\hline & 4-NP (ng/L) & $5.76^{\mathrm{b}}$ & $1647(863,5818)$ & $440(124,961)^{*}$ & $616(229,8228)^{\circ 0}$ & $386(100,752)$ & $124(279,796)$ & $286(149,1601)$ & 300 \\
\hline & $\mathrm{NP}_{1} \mathrm{EC}(\mathrm{ng} / \mathrm{L})$ & $4.12^{\mathrm{d}}$ & $113(49,606)$ & $82(19,180)^{*}$ & $202(54,608)$ & $105(46,587)^{*}$ & $81(19,179)$ & $105(40,598)^{\circ 0}$ & - \\
\hline & $\mathrm{NP}_{1} \mathrm{EO}(\mathrm{ng} / \mathrm{L})$ & $4.17^{d}$ & $366(116,1294)$ & $103(<31,478)^{*}$ & $81(158,627)$ & $38(<31,628)$ & $87(<31,421)$ & $79(<62,304)^{* *}$ & - \\
\hline & $\mathrm{NP}_{2} \mathrm{EO}(\mathrm{ng} / \mathrm{L})$ & $4.21^{d}$ & $220(99,2279)$ & $97(<62,362)^{* *}$ & $151(66,5108)$ & $180(<62,858)$ & $89(<62,355)$ & $93(<31,423)^{* *}$ & - \\
\hline \multirow{5}{*}{ 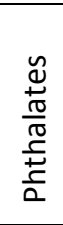 } & $\mathrm{DMP}(\mu \mathrm{g} / \mathrm{L})$ & $1.59^{b}$ & $0.44(0.33,1.14)$ & $0.32(<0.25,1.17)^{* *}$ & $0.32(0.27,1.01)$ & $<0.25(<0.25,1.0)$ & $<0.25(<0.25,1.1)$ & $<0.25(<0.25,0.94)$ & - \\
\hline & $\operatorname{DiBP}(\mu \mathrm{g} / \mathrm{L})$ & $4.27^{b}$ & $2.8(1.2,21)$ & $2.0(0.52,15)$ & $2.35(1.39,9.7)$ & $1.3(<0.52,7.5)$ & $1.5(<0.52,15)$ & $1.1(<0.52,8.1)$ & - \\
\hline & DBP $(\mu \mathrm{g} / \mathrm{L})$ & $4.56^{\mathrm{b}}$ & $1.7(0.6,21)$ & $1.2(0.19,8.1)^{* *}$ & $1.1(0.58,8.9)$ & $0.28(0.82,8.28)$ & $0.68(0.19,7.7)$ & $0.69(<0.18,8.0)$ & - \\
\hline & $\mathrm{DEHP}(\mu \mathrm{g} / \mathrm{L})$ & $7.45^{b}$ & $14(4.6,130)$ & $6.4(1.8,57)$ & $13(3.9,120)$ & $3.4(0.88,12)$ & $2.7(1.4,57)$ & $4.7(1.2,18)^{\circ 0}$ & 1.3 \\
\hline & DNP $(\mu \mathrm{g} / \mathrm{L})$ & $9.52^{\mathrm{a}}$ & $0.20(<0.14,12)$ & $0.14(0.11,0.80)^{*}$ & $0.15(0.12,1.5)^{* *}$ & $<0.11(<0.11,0.95)$ & $<0.11(<0.11,0.14)$ & $<0.11(<0.11,0.13)$ & - \\
\hline
\end{tabular}

Table 7: Median (minimum, maximum) total and dissolved concentrations observed for BPA, alkylphenol (AP) and phthalate (PAE) in road runoff (RR), the vegetative filter strip (VFS) and the biofiltration swale (BFS), compared to European (EC, 2013) annual mean environmental quality standards. Octanol-water partition coefficient (log Kow), median ${ }^{a}$ (U.S. National Library of Medicine, 2018), ${ }^{b}$ (Mackay, 2006), '(European Chemicals Agency, 2018), ${ }^{d}(B e r g e ́$ et al., 2012). Significant concentration reductions at BFS or VFS outlets compared to RR represented by ${ }^{*}(\mathrm{P}<0.01)$ or ${ }^{* *}(\mathrm{P}<0.05)$; increases by ${ }^{\circ}(\mathrm{P}<0.01)$ or ${ }^{\circ}(\mathrm{P}<0.05)$. 


\subsection{Treatment efficiency}

Treatment efficiency results for TSS, OC, trace metals and organic micropollutants are presented below; those for other global parameters are presented in Supplementary Information.

\subsubsection{Global Parameters}

TSS concentrations (Table 4) were significantly reduced for both VFS and BFS (Wilcoxon $\mathrm{P}<0.01$ ). Outlet VFS TSS concentrations were generally lower than those from BFS (median concentration reductions, $E_{c 50}$, of 94 and $92 \%$ respectively, Table S3 in Supplementary Information). While previous studies have shown that biofiltration tends to have high TSS removals, these are among the best removal rates reported in the literature (Brown and Hunt, 2011; Davis, 2007; DiBlasi et al., 2009; Hsieh and Davis, 2005; Leroy et al., 2016).

However, degraded performance was observed for three events, which can be observed in the TSS probability distribution (Figure 3 ) as a discontinuity between the majority of the series and the three highest concentrations for both BFS and VFS. These events all occurred in winter 2017 (Figure S12, Supplementary Data), a period when road salt was frequently applied. One possible explanation for this behavior is the dispersion and erosion of clay particles under sodic conditions introduced by $\mathrm{NaCl}$-rich runoff water, a phenomenon which has been previously observed in both field (Winston et al., 2012) and column (McManus and Davis, 2017) studies of LID devices. However, because colloid dispersion generally occurs under sodic conditions with low salinity (Shainberg and Letey, 1984), this effect is generally not expected for events immediately following salt application but in later events when low-salinity water is filtered through the sodic soils (Norrström, 2005). Alternatively, this performance may be caused by a degradation in the efficiency of filtration of road runoff TSS particles, due to cracks in the filter media or less treatable particles during this period.

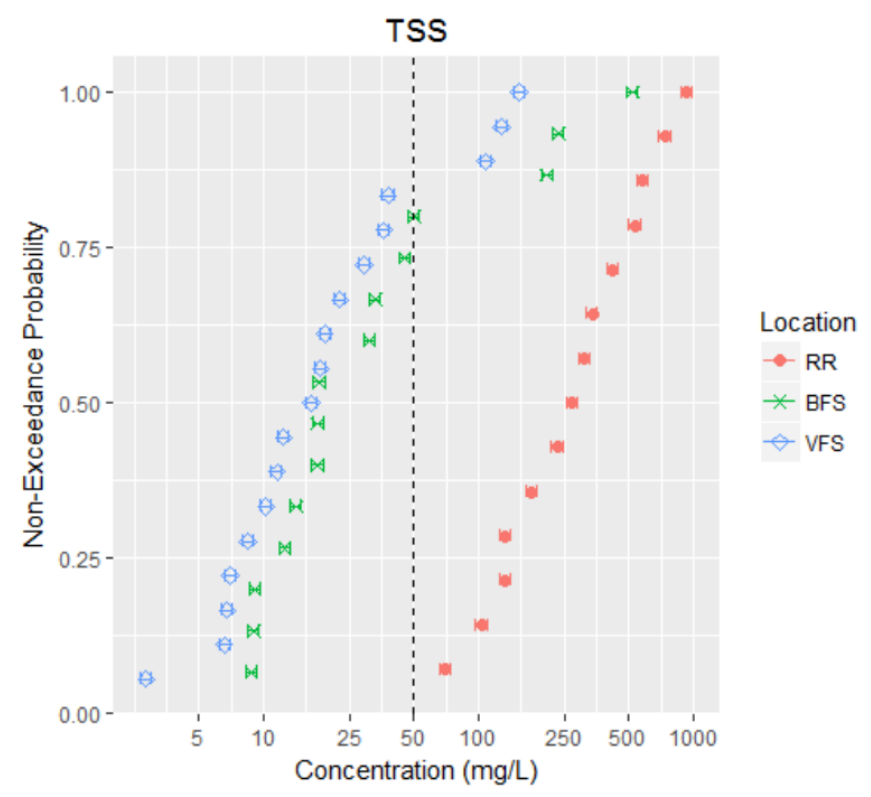

Figure 3: Probability distribution of TSS concentrations in road runoff (RR), the vegetative filter strip (VFS) and the biofiltration swale (BFS); Y-axis represents the experimentally observed probability of not exceeding the associated observed concentration (X-axis). Error bars represent analytical uncertainty while the dotted black line represents the water quality objective.

Total concentrations of $\mathrm{OC}$ were significantly reduced at both outlets (Wilcoxon $\mathrm{P}<0.01$ ), while dissolved OC concentrations were significantly higher at both outlets than in RR (Wilcoxon $P<0.01$ for VFS and $\mathrm{P}<0.05$ for BFS). Dissolved OC concentrations were higher at VFS than BFS, probably due to 
an accumulation of organic material over time and more biological activity leading to its degradation in the older system.

\subsubsection{Trace metals}

In the total phase, all trace metal concentrations were significantly reduced (Wilcoxon: $P<0.01$, except As for the BFS for which $\mathrm{P}<0.05$ ). Removals were also usually analytically significant (i.e. superior to analytical uncertainty) with the exception of $33 \%$ of events for As and $11 \%$ of events for $\mathrm{Cr}$ and $\mathrm{V}$ at BFS. VFS removed total trace metals better than BFS, likely due to better removal of particles (Table S3). $\mathrm{Pb}$ and $\mathrm{Zn}$ were the best removed species, while As was the least well removed in both systems. $\mathrm{Cu}, \mathrm{Zn}$ and $\mathrm{Pb} \mathrm{E}_{\mathrm{c} 50}(77,93$ and $90 \%$ and 76, 89 and $89 \%$ for the VFS and BFS, respectively) were higher than those previously reported for similar systems (Davis, 2007; Leroy et al., 2016).

The treatment of dissolved trace metals was shown to be much less effective. Negative $E_{c 50}$ were observed for VFS for $\mathrm{As}, \mathrm{Cr}, \mathrm{Cu}, \mathrm{Ni}$ and $\mathrm{Pb}$. Although many of these concentration increases were analytically significant for certain events, none were significant for the full series (Wilcoxon $P>0.05$ ). At $\mathrm{BFS}$, negative $E_{c}$ for $\mathrm{As}, \mathrm{Cr}$ and $\mathrm{V}$ were analytically significant for most events as well as for the full series (Wilcoxon $\mathrm{P}<0.05$ ). Analytically significant, positive $\mathrm{E}_{\mathrm{c}}$ were often observed for dissolved $\mathrm{Cu}, \mathrm{Pb}$ and $\mathrm{Zn}$ for BFS and for $\mathrm{V}$ and $\mathrm{Zn}$ for VFS, though the removal was not significant across the full series (Wilcoxon $P>0.05$ ) due to inter-event variability. As a results of this low performance, the EQS was systematically surpassed for $\mathrm{Cu}$ at both treatment sites, and $70 \%$ and $87 \%$ of events for zinc in the BFS and VFS, respectively.

Probability distributions of most total trace metals tend to closely resemble those of TSS, particularly in the case of $\mathrm{Zn}$ (Figure 4). An exception to this is the lower portion of the BFS distribution, for which $\mathrm{Zn}$ concentrations are especially low. These concentrations were measured during the earliest period of BFS functioning (Figure S12, Supplementary Information) when uncontaminated, fine soil particles were probably being washed out from the new filter media; as such, particle concentrations of $\mathrm{Zn}$ were particularly low during this period. Distributions of other elements, such as $\mathrm{Cu}$, had a less marked discontinuity in the VFS distribution. In both of these cases, dissolved distributions show quite different behavior, with higher concentrations observed in VFS than BFS, possibly due to the leaching of pollutants accumulated over time in the filter media.

The probability distribution of As demonstrates behavior indicative of emissions from the filter media. Although the highest total concentrations at BFS are below those observed in RR, no improvement is observed at lower levels, as As levels in outlet water appear to approach a irreducible concentrations due to equilibrium with the soil. Dissolved BFS concentrations always exceed those in RR. The lower dissolved concentrations observed at VFS indicate that leaching from the filter media may decrease over time. 


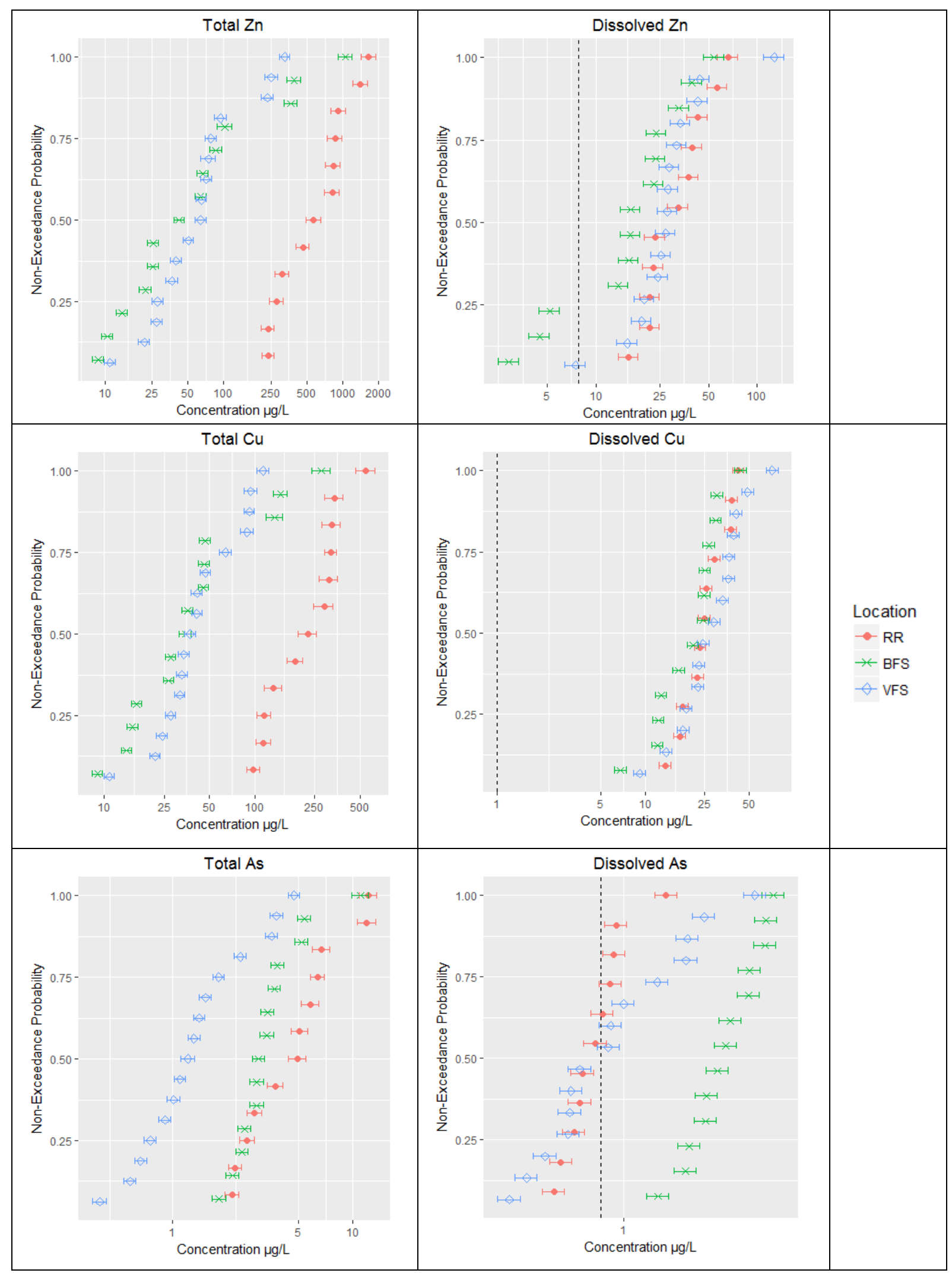

Figure 4 : Probability distributions of total and dissolved $\mathrm{Zn}, \mathrm{Cu}$ and As concentrations in road runoff (RR), the vegetative filter strip (VFS) and the biofiltration swale (BFS). Y-axis represents the experimentally observed probability of not exceeding the associated observed concentration (X-axis). Error bars represent analytical uncertainty while the dotted black line represents the EQS. 


\subsection{3. $\mathrm{TPH}$ and $\mathrm{PAH}$}

TPH were significantly removed across events $\left(\mathrm{E}_{c 50} 71\right.$ and $64 \%$ for the VFS and BFS, respectively, Table S4) in the total phase and were never quantified in the dissolved phase.

Overall, both systems were shown to significantly remove total PAH (Wilcoxon: $\mathrm{P}<0.01$ for $\Sigma 16 \mathrm{PAH}$ ). Very high $E_{c 50}$ (91\% for both systems for $\Sigma 16 \mathrm{PAH}$ ) were observed, consistent with concentration reductions observed by Diblasi et al. (2009) and David et al. (2015), both systems in which high TSS retention was also observed, but differing greatly from the results of Leroy et al. (2016), who observed low removal or even increases of PAH concentration from vegetative infiltration swales which also exhibited remarkably poor TSS removal.

In both systems at the event scale, most individual PAH molecule total $E_{c}$ were analytically significant, despite high analytical uncertainty, due to large differences between inlet and outlet concentrations. $E_{c 50}$ were lower (47-88\%) for several low molecular weight (LMW) PAH (Nap, 1MN, 2MN, Acy, Acen, $\mathrm{F}, \mathrm{A})$ as well as one high molecular weight (HMW) molecule (DahA). These molecules are those present at the lowest proportions in RR (Figure S2, Supplementary Information), which explains, at least partially, the lower efficiency, due both to limitations in observed $E_{c}$ from the $L Q$ and to the fact that irreducible environmental concentrations may be closer to those observed in runoff. In addition, LMW PAH are expected to be more mobile in soil than their more hydrophobic, HMW counterparts.

Across events, concentrations of all molecules in the VFS and most molecules in the BFS were significantly lower than those in RR (Wilcoxon $\mathrm{P}<0.01$ ). However, as total BFS outlet concentrations of Nap, $1 \mathrm{MN}, 2 \mathrm{MN}$ and Acen were higher than those in RR for some events, their reduction was not found to be significant $(P>0.05)$. Nap, $1 \mathrm{MN}$ and $2 \mathrm{MN}$ concentrations were only elevated in this way for a single event, likely due to a one-time, local leak or spill of a petroleum product from a vehicle (Stogiannidis and Laane, 2015), while those of Acen were high for all events sampled in the first three months of operation.

Among the pollutants regulated by the European Water Framework Directive, Nap was always below the EQS at both sites, while A exceeded its standard for a single event at BFS and both Fluo and BaP systematically exceeded the EQS at both sites.

In the dissolved phase, only Phen, Fluo and Pyr were systematically quantified in RR. As many outlet concentrations were below the $L Q$, calculated event $E_{c}$ were often lower bounds and found to be analytically insignificant. For VFS, all three molecules, and for BFS, only Phen were significantly removed across events (Wilcoxon: $P<0.01$ ). BFS dissolved Acen concentrations were actually found to be significantly higher $(P<0.05)$ than those in $R R$.

Probability distributions of total and dissolved PAH (Figure 5) demonstrate the variety of behaviors observed. The distribution of Acen, both in the total and dissolved phases, is dominated by the high concentrations of dissolved Acen in the first period of operation of the BFS (Figure S12, Supplementary Information), after which total outlet concentrations were lower than those in RR. Lower outlet concentrations compared to RR are observed for total Fluo, BaP and BkF across the full distribution for both VFS and BFS, with lower performance for the highest three outlet concentrations, which correspond to the winter 2017 period (Figure S12). However, while a clear discontinuity is visible for $\mathrm{BaP}$ between these concentrations and the rest of the distribution, it is less marked than that observed for TSS, $\mathrm{Zn}$ and $\mathrm{Pb}$; such a discontinuity is even less visible for Fluo and BkF.

Like Acen, the highest dissolved BFS concentrations of Fluo exceeded those in RR, again during the first period of operation (Figure S12), as did those of Pyr. A possible explanation observation is the emission of these pollutants from materials used to construct the BFS, most likely the new strip of asphalt. Bitumen, the sealant used in this asphalt, has been shown to contain PAH, albeit at lower 
levels than in coal tar (IARC Working Group on the Evaluation of Carcinogenic Risks to Humans et al., 2013). Other PAH molecules are also likely to be present in this material; the observation of emissions for only Acen, Fluo and Pyr may mean that other molecules (especially heavier, more hydrophobic PAH molecules) are less easily leached from the material or better retained by the filter media before collection in the drain.

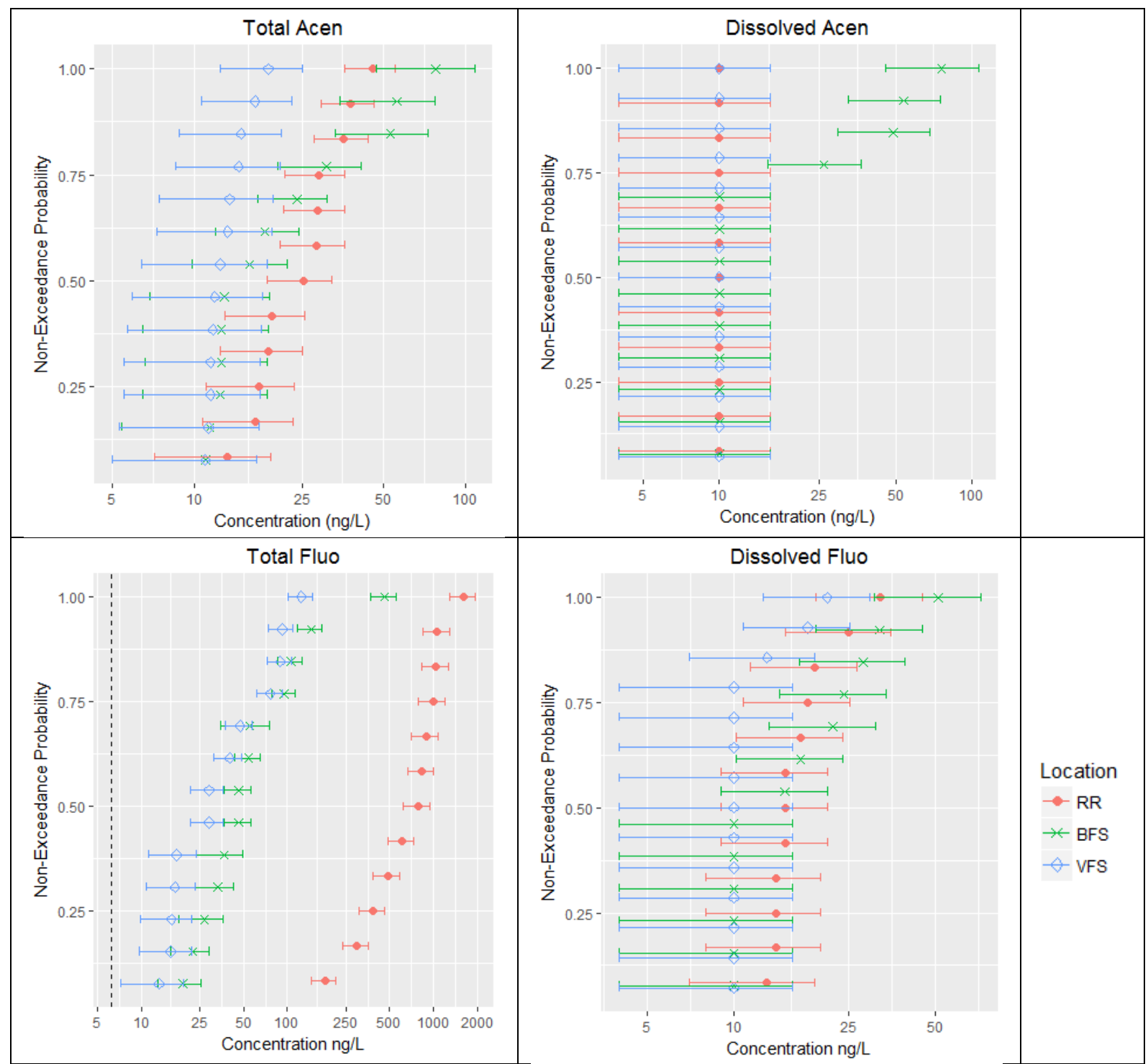




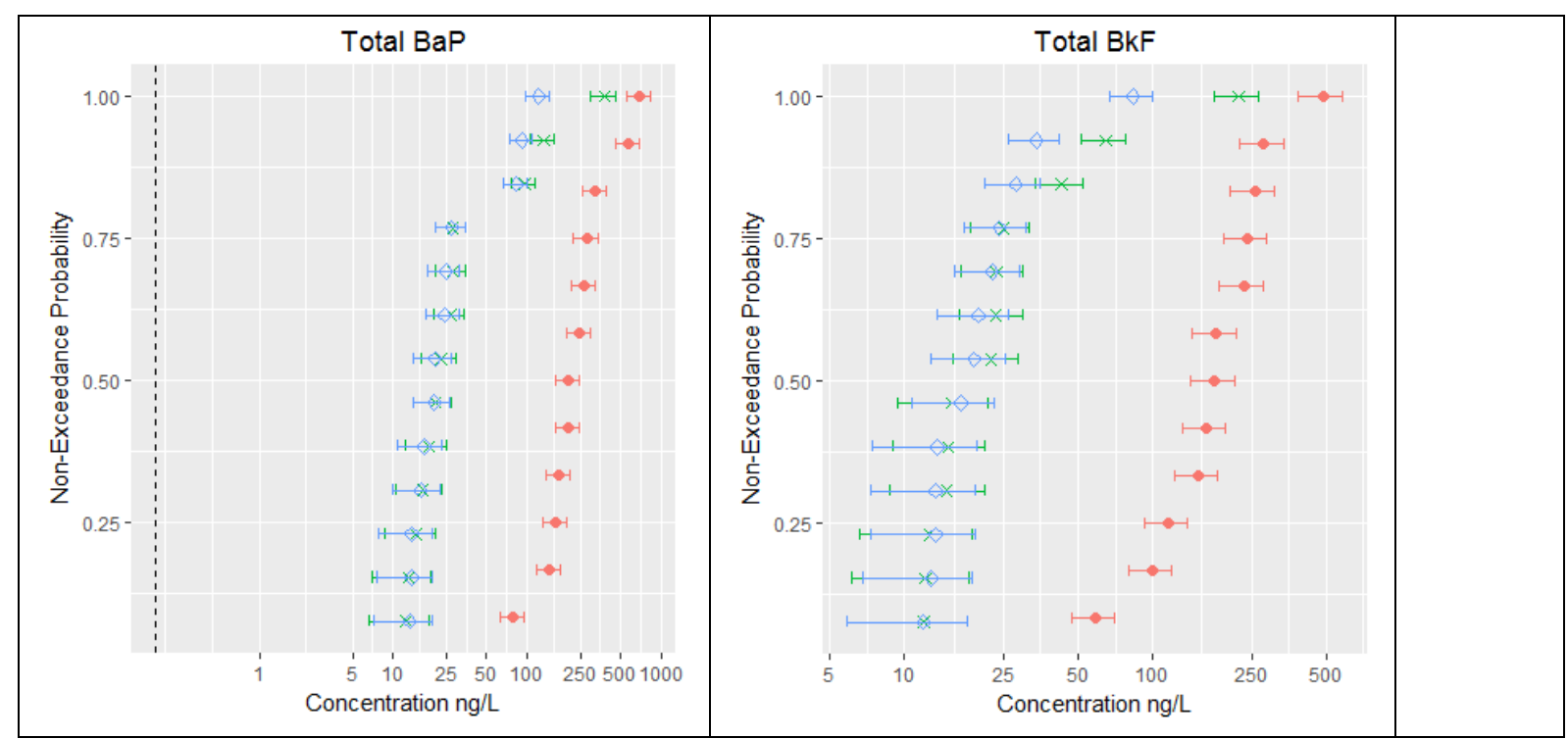

Figure 5: Probability distribution of total and dissolved Acen and Fluo and total $\mathrm{BaP}$ and $\mathrm{BkF}$ concentrations in road runoff (RR), the vegetative filter strip (VFS) and the biofiltration swale (BFS). Yaxis represents the experimentally observed probability of not exceeding the associated observed concentration (X-axis). Error bars represent analytical uncertainty while the dotted black line represents the EQS.

\subsubsection{Alkylphenols and Bisphenol-A}

In the VFS, total concentrations of BPA and all analyzed alkylphenols were found to be significantly reduced across events (Wilconxon $\mathrm{P}<0.01$ for all except $\mathrm{OP}_{1} \mathrm{EO}$ and $\mathrm{NP}_{2} \mathrm{EO}$, for which $\mathrm{P}<0.05$ ). However, as analytical uncertainties were high and the differences between RR and VFS drainage concentrations were less marked than for PAH, only BPA and OP displayed analytically significant removals for all events, while between $45-91 \%$ of removals were significant for the other alkylphenols (Table $S 5)$. The least well-retained species was $\mathrm{NP}_{1} \mathrm{EC}\left(\mathrm{E}_{\mathrm{c50}} 32 \%\right)$, likely due to its more dissolved character than the other pollutants as well as the fact that it may be the product of degradation of more abundant ethoxylated nonylphenols (Bergé et al., 2012). BPA and OP were found to be very well removed (median $\mathrm{E}_{\mathrm{c}} 86$ and $93 \%$, respectively).

Total $E_{c}$ tended to be lower for $B F S$, and the only statistically significant concentration reduction across events was found for BPA (Wilcoxon $P<0.05$ ). Again, negative $E_{c}$ were sometimes observed. Most notably, $\mathrm{NP}_{1} \mathrm{EC}$ concentrations significantly increased over the full series (Wilcoxon $\mathrm{P}<0.05$ ). The concentrations of other molecules only increased for one or two events, most commonly in May 2016 or winter 2017. Again, BPA and OP were the best removed contaminants of this family $\left(E_{c 50} 57\right.$ and $76 \%$ respectively).

In the dissolved phase, significant removals of $B P A, N P_{1} E C$ and $O P$ were observed over the full series for VFS (Wilcoxon $\mathrm{P}<0.01$ and $\mathrm{E}_{\mathrm{c} 50}$ of 79,27 and $74 \%$, respectively). Again, for most molecules in this family, removals were not analytically significant for all events. In the dissolved phase, negative $E_{c}$ were more often observed than in the total phase.

As in the total phase, concentrations of dissolved $\mathrm{NP}_{1} \mathrm{EC}$ increased significantly at the outlet of $\mathrm{BFS}$ (Wilcoxon $\mathrm{P}<0.05$ ). Removals of dissolved $\mathrm{OP}, \mathrm{NP}_{1} \mathrm{EO}$ and $\mathrm{NP}_{2} \mathrm{EO}$ were significant $(\mathrm{P}<0.05)$. At the event scale, the proportions of analytically significant reductions were relatively small, and negative $E_{c}$ were occasionally observed for all pollutants in this family besides $\mathrm{OP}_{1} \mathrm{EO}$ and $\mathrm{OP}_{2} \mathrm{EO}$, which were rarely quantified. 
The EQS for NP and OP were exceeded for 73 and $20 \%$ of events for the VFS and 75 and $33 \%$ for the BFS.

Probability distributions of BPA, OP and NP (Figure 6) differ from the forms observed for other pollutant families. BPA, much less particulate than trace metals or PAH, has a similar behavior in the dissolved and total phases, with slightly higher removals in the total phase. BFS dissolved concentrations appear to approach a non-reducible level at around $100 \mathrm{ng} / \mathrm{L}$, which may be indicative of emissions from synthetic materials used in the construction of this system (the asphalt, geomembrane, drain or drain filter fabric). VFS concentrations are consistently lower than those in $\mathrm{RR}$, with slightly less difference at the highest concentrations. BFS concentrations follow a similar distribution, albeit with higher concentrations, approaching those in RR at the highest levels. While total NP concentrations are strongly reduced over the whole distribution range for VFS and over the lower half of the distribution range for BFS, little improvement is seen in the dissolved phase. Indeed, the highest and lowest concentrations at both VFS and BFS exceed those of RR. Besides this, outlet concentrations from BFS and VFS are very similar and consistently slightly lower than those in RR, though within in the range of its uncertainty.

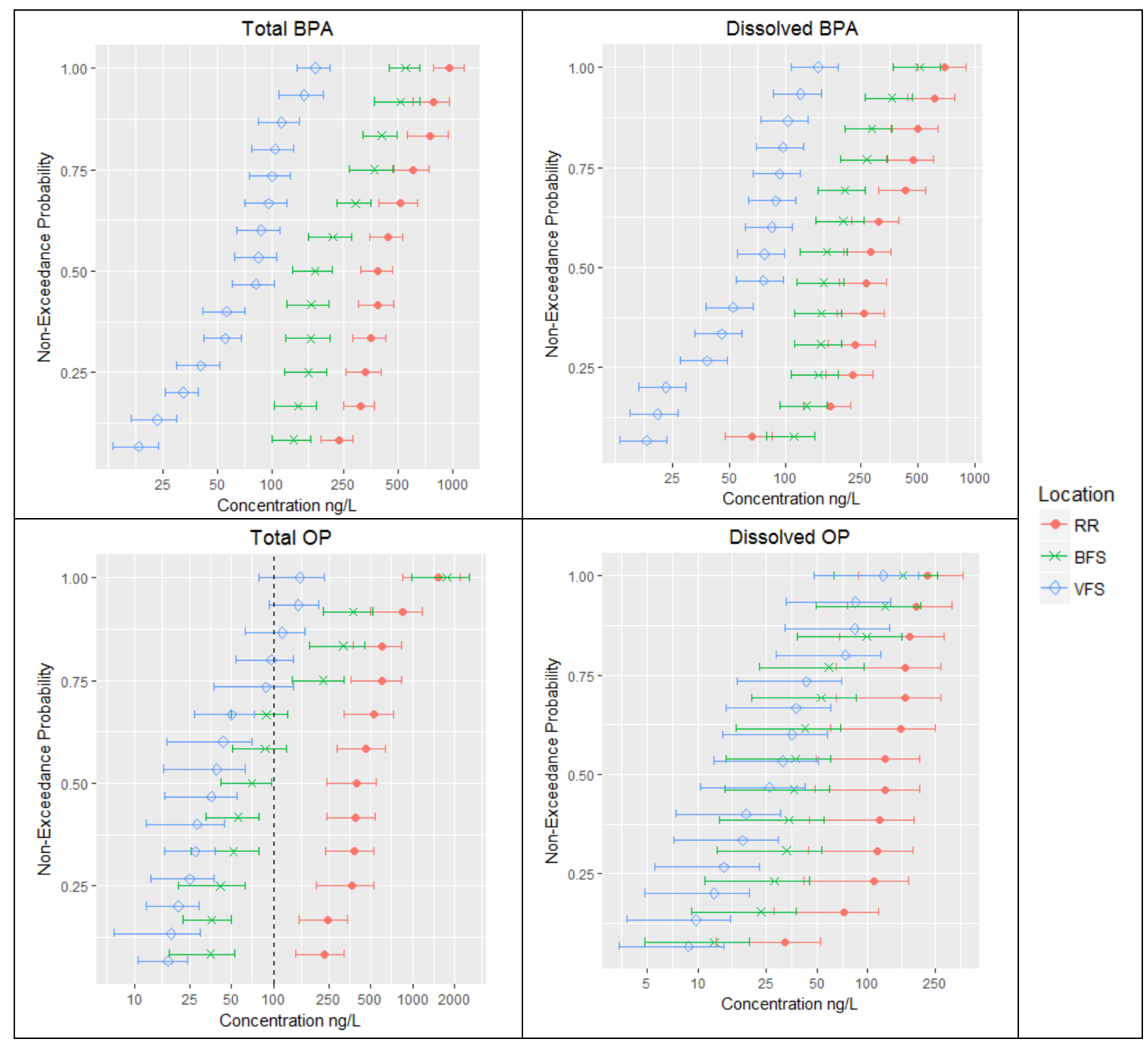




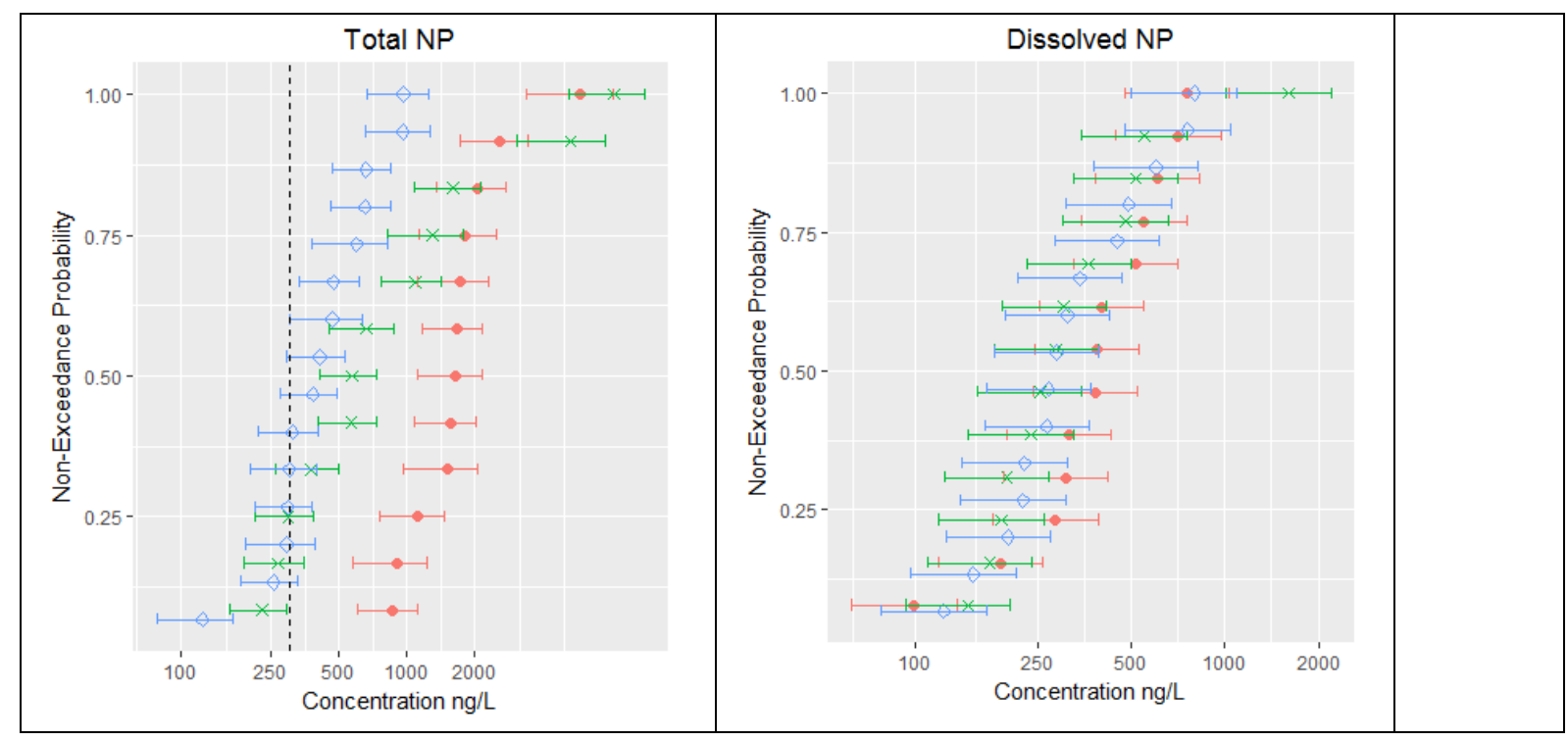

Figure 6: Probability distribution of total and dissolved BPA, OP and NP concentrations in road runoff $(R R)$, the vegetative filter strip (VFS) and the biofiltration swale (BFS). Y-axis represents the experimentally observed probability of not exceeding the associated observed concentration (X-axis). Error bars represent analytical uncertainty while the dotted black line represents the EQS.

\subsubsection{Phthalates}

All $E_{c 50}$ for total phthalates were positive (Table S5), though lower than those observed for metals and PAH. Outlet concentrations were only significantly below those in RR across the series for DNP (Wilcoxon $\mathrm{P}<0.01), \mathrm{DMP}$ and DBP $(\mathrm{P}<0.05)$ at VFS and DNP $(\mathrm{P}<0.05)$ at $\mathrm{BFS}$. In addition, the proportion of events with analytically significant reductions were low $(<70 \%)$ for all pollutants except DNP. Higher $E_{c}$ tended to be observed for the heavier, more particulate molecules. An exception to this is DEHP in the BFS, which has the lowest $E_{c 50}$ of any phthalate, despite its mainly particulate nature in RR. Concentrations of DEHP always exceeded the EQS, even in outlet water.

No significant reductions of dissolved concentrations were observed for the full series, and negative $E_{c}$ were observed sporadically for all phthalates. Dissolved concentrations of DEHP actually increased significantly (Wilcoxon $\mathrm{P}<0.05$ ), which indicates that a source of DEHP is present in the BFS, likely materials used in its construction: asphalt (Markiewicz et al., 2017), a HDPE drain, the drain's synthetic filter fabric or a PVC geomembrane (Bergé et al., 2013).

$\mathrm{E}_{\mathrm{c} 50}$ for DEHP and DBP (47 and $69 \%$ for VFS and 8 and $48 \%$ for BFS) were lower than those observed by Zhang et al. (2014) (>97 and $>92 \%$, respectively) for synthetic runoff. Besides the possibility of phthalate sources among construction materials, this may be due to the less reactive (colloidal, for example) form of these pollutants in real rather than synthetic runoff (Kalmykova et al., 2013).

The probability distribution of DEHP (Figure 7) demonstrates the observed variability of treatment efficiency. VFS concentrations tend to be lower than those at BFS and RR, demonstrating that the system is capable of reducing concentrations. However, at low exceedance probabilities, VFS concentrations begin to overlap those in BFS and RR. In the dissolved phase, while VFS and BFS concentrations are of the same order as those in RR in the lower range of the probability distribution, peak concentrations exceed those in RR. This variable performance is visible to a lesser extent for DBP and DiBP, while those of DNP and DMP (Supplementary Data) show more consistent water quality improvement at the outlets, although the observation of the extent of treatment of these two compounds is limited by their proximity to the $L Q$. 


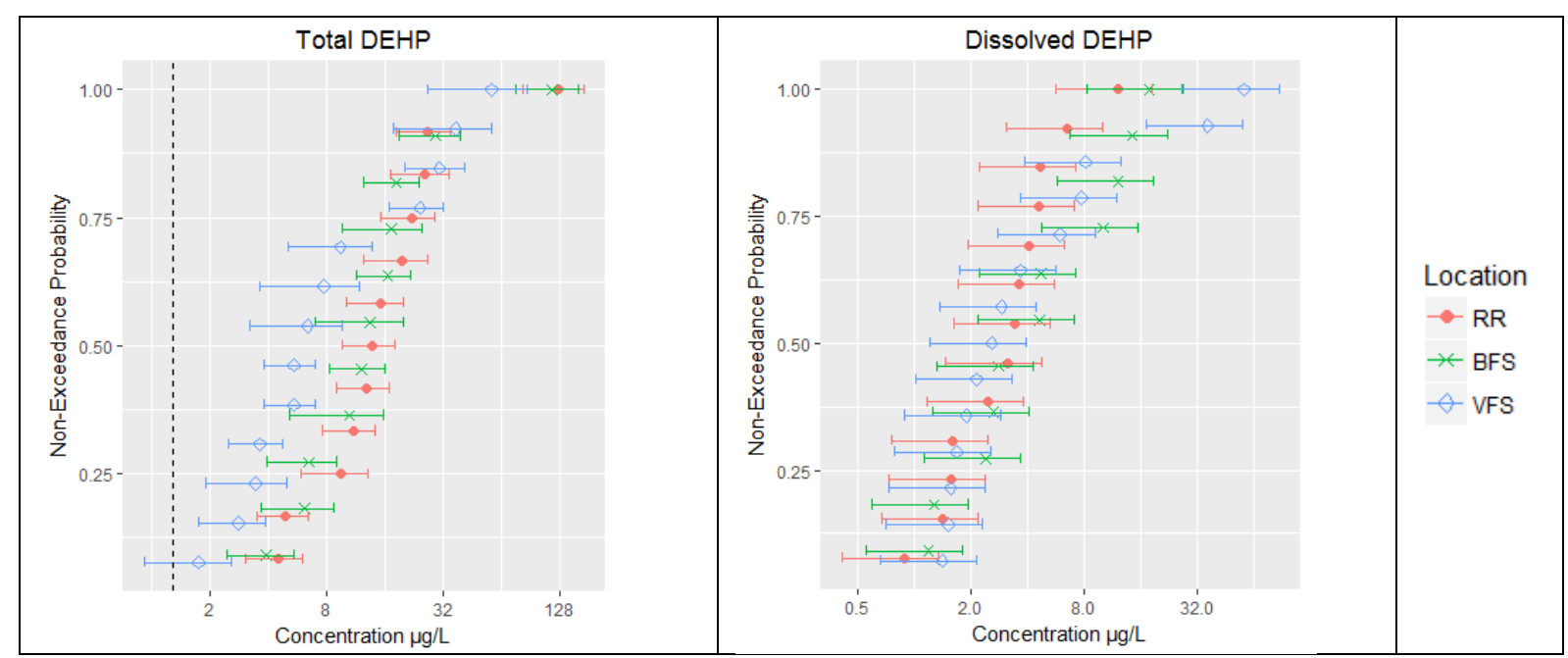

Figure 7: Probability distribution of total and dissolved DEHP concentrations in road runoff (RR), the vegetative filter strip (VFS) and the biofiltration swale (BFS). Y-axis represents the experimentally observed probability of not exceeding the associated observed concentration (X-axis). Error bars represent analytical uncertainty while the dotted black line represents the EQS.

\section{Discussion}

\subsection{Relationship between performance and pollutant properties}

Considering all trace metals and organic micropollutants, total $E_{c 50}$ were found to be significantly correlated with the median fraction of each species found in the particulate phase $\left(F_{p 50}\right)$ (Spearman $\mathrm{P}<0.01$ for VFS and BFS), highlighting the generally more efficient removal of particles than the dissolved phase of pollutants. BPA is an outlier in this relationship as it is relatively well removed despite its mainly dissolved character. This relationship was more dispersed in the BFS than the VFS (Figure 8), apparently due to the dissolved phase emissions of certain species in this system (As, Ba, $\checkmark$, Acen, DEHP).

For organic pollutants, $\mathrm{F}_{\mathrm{p} 50}$ was found to be significantly correlated with the pollutants' hydrophobicity, represented by its octanol-water partition coefficient, $\mathrm{K}_{\text {ow }}$ (Spearman $\mathrm{P}<0.01$ ). However, partitioning varied greatly between events for many pollutants (Figure S13 in Supplementary Information); one reason for this is likely to be variations in TSS concentrations. In addition, some molecules were systematically more particulate than others with a similar $\mathrm{K}_{\mathrm{ow}}$. This was notably the case for PAH, which were more particulate than alkylphenols or phthalates with similar $\mathrm{K}_{\mathrm{ow}}$, possibly indicating PAH to have more particulate sources that are not readily exchanged with the dissolved phase. On the other hand, pollutants which were particularly dissolved for a given $\mathrm{K}_{\mathrm{ow}}$, may be in the colloidal rather than truly dissolved phase (Kalmykova et al., 2013). 546.

Although $\mathrm{K}_{\mathrm{ow}}$ was also found to be significantly correlated with total $\mathrm{E}_{\mathrm{c} 50}$ for organic micropollutants (Spearman $\mathrm{P}<0.01$ for $\mathrm{VFS}, \mathrm{P}<0.05$ for $\mathrm{BFS}$ ), this relationship is quite dispersed, with different behavior exhibited for different pollutant families and between the two systems (Figure 8). The correlation which does exist appears to be mainly driven by the more particulate nature of more hydrophobic compounds, both because the relationship between $\mathrm{K}_{\mathrm{ow}}$ and $\mathrm{E}_{\mathrm{c} 50}$ (Figure 8) strongly resembles that between $\mathrm{K}_{\mathrm{ow}}$ and $\mathrm{F}_{\mathrm{p} 50}$ in RR (Figure S13) and because no significant correlation was observed between $\mathrm{K}_{\text {ow }}$ and dissolved $\mathrm{E}_{\mathrm{c50}}$ in either system (Spearman $\mathrm{P}>0.05$, Figure S14).

The limited relationship between $\mathrm{K}_{\text {ow }}$ and $\mathrm{E}_{c 50}$ (Figure 8) indicates that other factors besides the pollutant's hydrophobicity determine its partitioning and fate in biofiltration systems. One reason for this may be the chemical speciation of pollutants; indeed, Kalmakova et al. (2013) demonstrated that alkylphenols, phthalates, BPA and PAH may all be present in the colloidal phase in stormwater. Chemical speciation may also explain relatively low adsorption of dissolved metals. Other 
explanations may be the irreducible concentrations of some pollutants due to background filter media concentrations (this is the case of $\mathrm{PAH}$ ), emissions of certain pollutants from synthetic materials used to construct the systems (asphalt, geomembrane, drain or drain filter fabric) or other fate processes which might also lead to concentration reduction. For example, the high removals of dissolved phase BPA despite its relatively hydrophilic nature may be due to its biodegradability. Indeed, previously reported biodegradation half-lives between 2.5-4 days (U.S. National Library of Medicine, 2018), this process could be important at the time scale of filtration (residence times typically 12-72 hours in the BFS and 14-58 hours in the VFS).
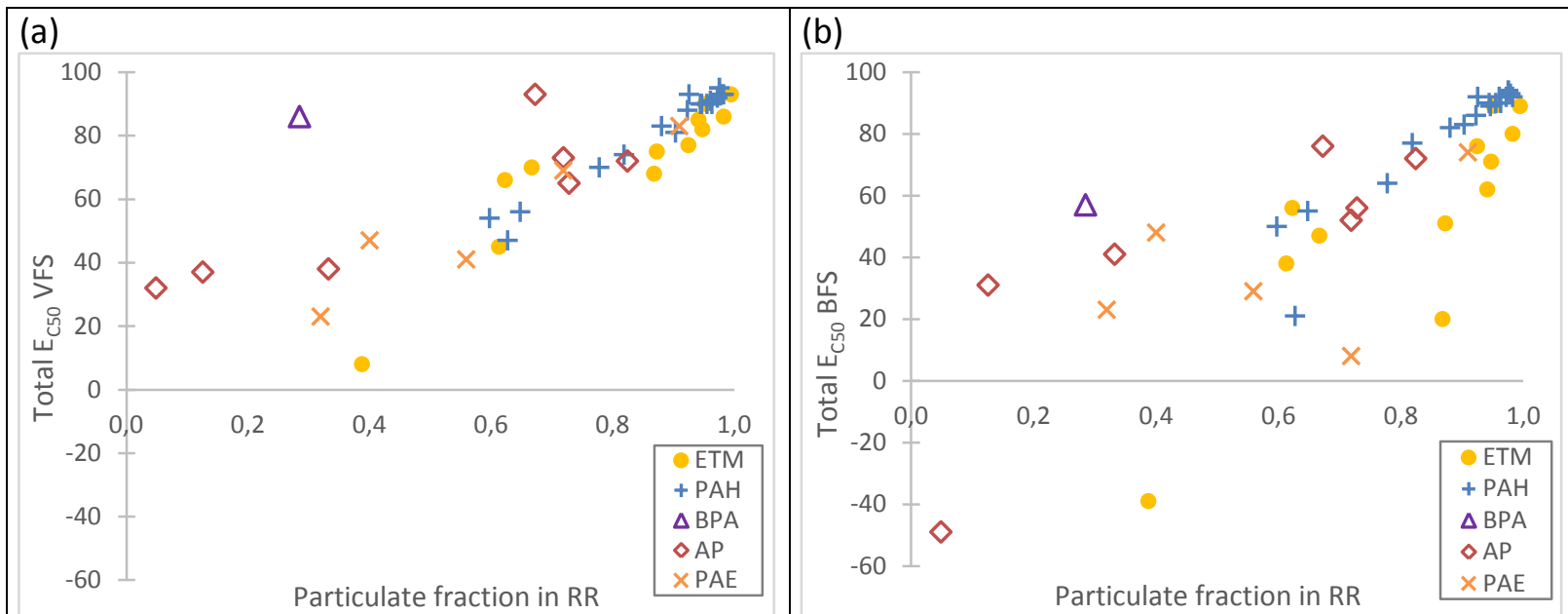

(c)

(d)
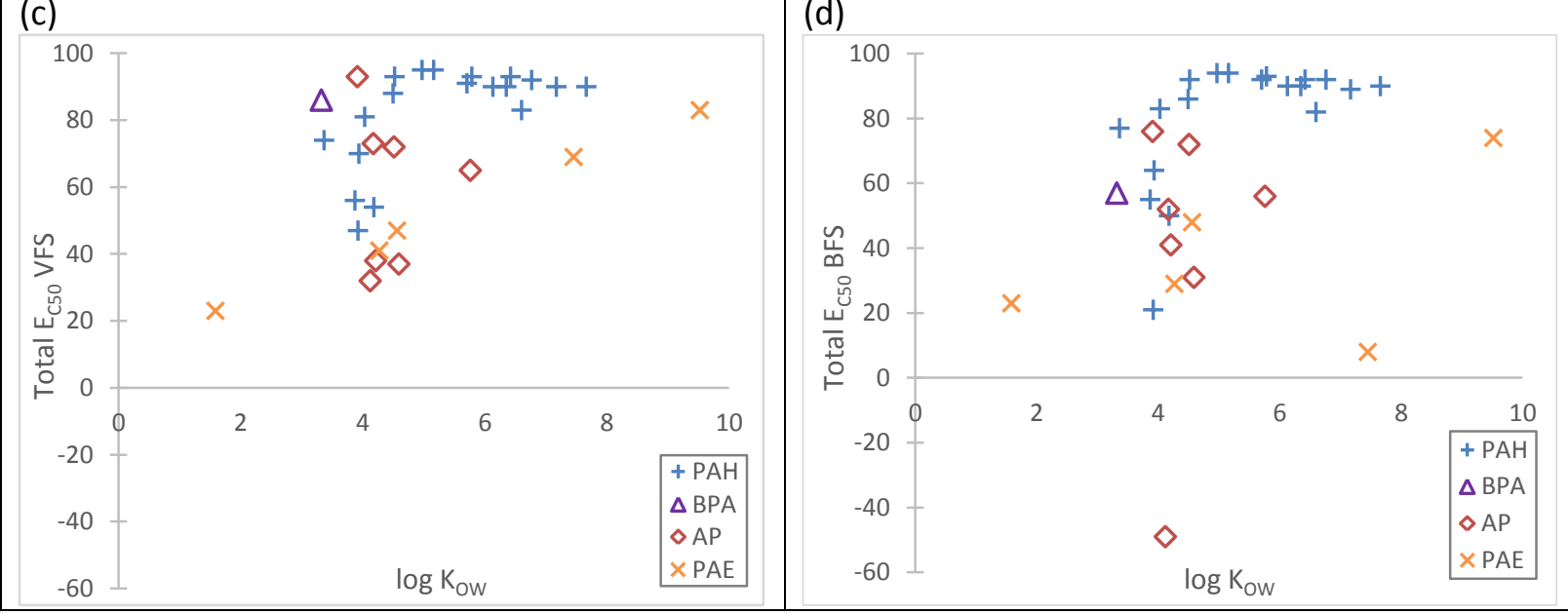

Figure 8: Relationships between total median concentration reduction $\left(\mathrm{E}_{c 50}\right)$ and median particulate fraction $\left(F_{p 50}\right)$ in (a) the vegetative filter strip, VFS and (b) the biofiltration swale, BFS and between total $E_{c 50}$ and octanol water partition coefficient $\left(K_{o w}\right)$ in (c) VFS and (d) BFS 


\subsection{Comparison of the two biofiltration systems}

Many of the differences observed between the VFS and BFS systems can be attributed to age differences. This is notably the case for the slightly higher TSS concentrations at the BFS outlet, which may be attributed to the wash out of fine particles from the not yet stabilized filter media, as well as the emissions of some dissolved trace metals from the initial filter media in the BFS (As, Ba, Sr, V). In this case, the differences observed between the BFS and VFS systems demonstrate improvements in performance as the filter media stabilizes. On the other hand, higher concentrations of dissolved OC, $\mathrm{Cu}, \mathrm{Pb}$ and $\mathrm{Zn}$ concentrations at the VFS outlet may indicate decreased performance as these elements accumulate in the filter media over time.

Most organic micropollutants (some PAH, BPA, alkylphenols and phthalates) were observed in higher concentrations in the BFS than the VFS, especially early on in the study. While the evolution in BFS outlet concentrations over the course of the study shows that performance may improve as materials reach equilibrium with their environment over time, this result highlights the fact that including synthetic materials in a biofiltration system designed to treat organic micropollutants which are ubiquitous in such materials (Björklund, 2010; Lamprea et al., 2018) is counterproductive. As the VFS only contains a sheet drain, as opposed to the asphalt, drain with filter fabric and geomembrane in the BFS, its better performance with respect to organic micropollutants is likely more representative of that which might be observed in a system without such materials.

When choosing a treatment device, it is also important to remember that a vegetative filter strip treats only water which infiltrates during its flow across the surface, while a biofiltration swale is designed to store runoff at the surface before its filtration. As such, for an identical surface area and filter media, a biofiltration swale may be expected to treat a greater volume than a vegetative filter strip. In addition, a design with surface storage is likely to be more resilient to the accumulation of sediment, which may compromise flow on vegetative filter strips after only a short period of operation on sites with high TSS concentrations (Flanagan, 2018).

\subsection{Uncertainties and challenges in data interpretation}

The evaluation of the efficiency of LID devices involves challenges in data acquisition and interpretation. First of all, each measured concentration includes uncertainties associated with both sampling and analysis, the latter of which may be particularly large for organic micropollutants and have thus been thoroughly accounted for throughout the present article. The use of a reference catchment for estimating inlet water quality is an additional source of uncertainty and potential bias. In the present case, the reference catchment was nearly identical to the BFS and VFS catchments, with the exception of the presence of a concrete border. While pollutant buildup processes are likely to be similar, the border modifies flow conditions and may modify the dynamics of pollutant washoff. As such, annual loads from each catchment should be similar, but event mean concentrations for each rain event could vary. Given these various issues, comparison of distributions of pollutant concentrations at each point for several events is a more robust tool for evaluating efficiency than comparing concentrations for each rain event, as such distributions include not only inter-event variability but also variability due to uncertainties.

Concerning treatment efficiency of dissolved pollutants and dissolved concentration levels, it is important to keep in mind that samples were filtered within 24 hours from the end of RR runoff. While it would have been very difficult to reduce this delay, especially given the time necessary for water to filter through the system (average residence time $>12$ hours), there is a possibility of some transfer between dissolved and particulate phases in the sample before analysis. Sansalone and Buchberger's work (1997) show that metals in road runoff can become more particulate after about a duration of 6 hours, which could lead to a underestimation of dissolved removal rates. On the other 
hand, some desorption of particulate pollutants in VFS and BFS samples after filtration is possible. It will however be limited by the low TSS concentrations in these samples.

\section{Conclusions}

The performance of two stormwater biofiltration systems treating road runoff were evaluated for a wide range of conventional pollutants and micropollutants for both total and dissolved concentrations. Key findings are as follows.

- Concentrations reductions of TSS and highly particulate contaminants (including zinc, copper, lead, TPH and PAH) were high $\left(E_{c}>90 \%\right)$ for most events, though a period of poor performance was observed over a particularly cold winter period.

- Treatment of dissolved-phase pollutants was less efficient, with relatively few significant dissolved pollutant concentrations observed. This performance was not correlated with hydrophobicity for organic micropollutants. Although median $E_{c}$ approached $80 \%$ for some pollutants, the majority were much lower, sometimes even negative. As such, removal of moderately particulate pollutants (BPA, alkylphenols, and phthalates) tended to be lower than the aforementioned highly particulate pollutants.

- Many pollutants (including some nutrients, PAH molecules, trace elements, BPA, alkylphenols and phthalates) demonstrate low or negative $E_{c}$ during the first months of operation of the BFS system. A major cause of this is thought to be emissions from components of the biofiltration system. While the filter medium is the most likely source of leached nutrients and trace metals, man-made materials including geomembranes, asphalt, drains and associated filter fabrics are potential sources of organic micropollutants, a fact while should be taken into account when designing biofilters for the treatment of micropollutants.

The present research has raised questions as to the mechanisms underlying the retention and transport of pollutants in stormwater biofilters, especially during winter. Better understanding these processes, as well as the fate of retained pollutants in these systems and long-term evolutions in performance, are important subjects for future research, which could improve recommendations for the conception and maintenance of biofiltration systems.

\section{Acknowledgements}

We also acknowledge the Seine-et-Marne Departmental Council, and especially Eric Thomas and Tina Ratovelomanana, for their partnership and technical support, as well as Tianran Dong, Delphine Truong, Thi Kim Phung Nguyen, Meriem Kajeiou and Maria Vitart de Abreu Lima for their help with sampling campaigns.

\section{Funding}

This work was supported by funding for the Roulépur research program (AFB and AESN), the Observatory of Urban Pollutants in Paris (OPUR) (AESN, SIAAP, CD92, CD93, CD94 and Ville de Paris), and a PhD scholarship from ENPC.

\section{Bibliography}

Agence Parisienne du Climat, Météo-France, 2015. Le changement climatique à Paris: évolution du climat à Paris depuis 1900, quel climat futur?

Bergé, A., Cladière, M., Gasperi, J., Coursimault, A., Tassin, B., Moilleron, R., 2013. Meta-analysis of environmental contamination by phthalates. Environmental Science and Pollution Research 20, 8057-8076. https://doi.org/10.1007/s11356-013-1982-5 
Bergé, A., Cladière, M., Gasperi, J., Coursimault, A., Tassin, B., Moilleron, R., 2012. Meta-analysis of environmental contamination by alkylphenols. Environmental Science and Pollution Research 19, 3798-3819. https://doi.org/10.1007/s11356-012-1094-7

Björklund, K., 2010. Substance flow analyses of phthalates and nonylphenols in stormwater. Water Science \& Technology 62, 1154. https://doi.org/10.2166/wst.2010.923

Björklund, K., Cousins, A.P., Strömvall, A.-M., Malmqvist, P.-A., 2009. Phthalates and nonylphenols in urban runoff: Occurrence, distribution and area emission factors. Science of The Total Environment 407, 4665-4672. https://doi.org/10.1016/j.scitotenv.2009.04.040

Bressy, A., 2010. Flux de micropolluants dans les eaux de ruissellement urbaines: Effets de différents modes de gestion des eaux pluviales. Université de Paris Est.

Bressy, A., Gromaire, M.-C., Lorgeoux, C., Saad, M., Leroy, F., Chebbo, G., 2012. Towards the determination of an optimal scale for stormwater quality management: Micropollutants in a small residential catchment. Water Research 46, 6799-6810. https://doi.org/10.1016/j.watres.2011.12.017

Brown, J.N., Peake, B.M., 2006. Sources of heavy metals and polycyclic aromatic hydrocarbons in urban stormwater runoff. Science of The Total Environment 359, 145-155. https://doi.org/10.1016/j.scitotenv.2005.05.016

Brown, R.A., Hunt, W.F., 2011. Underdrain Configuration to Enhance Bioretention Exfiltration to Reduce Pollutant Loads. Journal of Environmental Engineering 137, 1082-1091. https://doi.org/10.1061/(ASCE)EE.1943-7870.0000437

Clara, M., Windhofer, G., Hartl, W., Braun, K., Simon, M., Gans, O., Scheffknecht, C., Chovanec, A., 2010. Occurrence of phthalates in surface runoff, untreated and treated wastewater and fate during wastewater treatment. Chemosphere 78, 1078-1084. https://doi.org/10.1016/j.chemosphere.2009.12.052

David, N., Leatherbarrow, J.E., Yee, D., McKee, L.J., 2015. Removal Efficiencies of a Bioretention System for Trace Metals, PCBs, PAHs, and Dioxins in a Semiarid Environment. Journal of Environmental Engineering 141, 04014092. https://doi.org/10.1061/(ASCE)EE.19437870.0000921

Davis, A.P., 2007. Field Performance of Bioretention: Water Quality. Environmental Engineering Science 24, 1048-1064.

Davis, A.P., Hunt, W.F., Traver, R.G., Clar, M., 2009. Bioretention technology: Overview of current practice and future needs. Journal of Environmental Engineering 135, 109-117.

DiBlasi, C.J., Li, H., Davis, A.P., Ghosh, U., 2009. Removal and Fate of Polycyclic Aromatic Hydrocarbon Pollutants in an Urban Stormwater Bioretention Facility. Environmental Science \& Technology 43, 494-502. https://doi.org/10.1021/es802090g

EC, 2013. Directive 2013/39/EU of the European Parliament and of the Council of 12 August 2013 amending Directives 2000/60/EC and 2008/105/EC as regards priority substances in the field of water policy.

European Chemicals Agency, 2018. Substance Information.

Flanagan, K., 2018. Evaluation de la rétention et du devenir d'un panel diversifié de micropolluants dans un ouvrage de biofiltration des eaux de ruissellement de voirie. Université de Paris-Est.

Flanagan, K., Branchu, P., Ramier, D., Gromaire, M.-C., 2017. Evaluation of the relative roles of a vegetative filter strip and a biofiltration swale in a treatment train for road runoff. Water Science and Technology. https://doi.org/10.2166/wst.2016.578

Fletcher, T.D., Shuster, W., Hunt, W.F., Ashley, R., Butler, D., Arthur, S., Trowsdale, S., Barraud, S., Semadeni-Davies, A., Bertrand-Krajewski, J.-L., Mikkelsen, P.S., Rivard, G., Uhl, M., Dagenais, D., Viklander, M., 2014. SUDS, LID, BMPs, WSUD and more - The evolution and application of terminology surrounding urban drainage. Urban Water Journal 12, 525-542.

Gasperi, J., Sebastian, C., Ruban, V., Delamain, M., Percot, S., Wiest, L., Mirande, C., Caupos, E., Demare, D., Diallo Kessoo Kessoo, M., Saad, M., Schwartz, J.J., Dubois, P., Fratta, C., Wolff, H., Moilleron, R., Chebbo, G., Cren, C., Millet, M., Barraud, S., C Gromaire, M., 2014. Micropollutants in urban stormwater: occurrence, concentrations, and atmospheric 
contributions for a wide range of contaminants in three French catchments. Environmental Science and Pollution Research (8):5267-81. https://doi.org/10.1007/s11356-013-2396-0

GeoSyntec Consultants, Urban Drainage and Flood Control District, Urban Water Resources Research Council of ASCE, 2002. Urban Stormwater BMP Performance Monitoring.

Hatt, B.E., Fletcher, T.D., Deletic, A., 2009. Hydrologic and pollutant removal performance of stormwater biofiltration systems at the field scale. Journal of Hydrology 365, 310-321. https://doi.org/10.1016/j.jhydrol.2008.12.001

Helmreich, B., Hilliges, R., Schriewer, A., Horn, H., 2010. Runoff pollutants of a highly trafficked urban road - Correlation analysis and seasonal influences. Chemosphere 80, 991-997. https://doi.org/10.1016/j.chemosphere.2010.05.037

Hsieh, C.S., Davis, A.P., 2005. Multiple-event study of bioretention for treatment of urban storm water runoff. Water Science and Technology 51, 177-181.

Huber, M., Welker, A., Helmreich, B., 2016. Critical review of heavy metal pollution of traffic area runoff: Occurrence, influencing factors, and partitioning. Science of The Total Environment 541, 895-919. https://doi.org/10.1016/j.scitotenv.2015.09.033

Hunt, W.F., Jarrett, A.R., Smith, J.T., Sharkey, L.J., 2006. Evaluating Bioretention Hydrology and Nutrient Removal at Three Field Sites in North Carolina. Journal of Irrigation and Drainage Engineering 132, 600-608.

Hunt, W.F., Smith, J.T., Jadlocki, S.J., Hathaway, J.M., Eubanks, P.R., 2008. Pollutant Removal and Peak Flow Mitigation by a Bioretention Cell in Urban Charlotte, N.C. Journal of Environmental Engineering 134, 403-408. https://doi.org/10.1061/(ASCE)0733-9372(2008)134:5(403)

IARC Working Group on the Evaluation of Carcinogenic Risks to Humans, International Agency for Research on Cancer, Weltgesundheitsorganisation, International Agency for Research on Cancer (Eds.), 2013. IARC monographs on the evaluation of carcinogenic risks to humans, volume 103 ; bitumens and bitumen emissions, and some $\mathrm{N}$ - and S-heterocyclic aromatic hydrocarbons, IARC monographs on the evaluation of carcinogenic risks to humans. IARC Press, Lyon.

Kalmykova, Y., Björklund, K., Strömvall, A.-M., Blom, L., 2013. Partitioning of polycyclic aromatic hydrocarbons, alkylphenols, bisphenol A and phthalates in landfill leachates and stormwater. Water Research 47, 1317-1328. https://doi.org/10.1016/j.watres.2012.11.054

Kayhanian, M., Fruchtman, B.D., Gulliver, J.S., Montanaro, C., Ranieri, E., Wuertz, S., 2012. Review of highway runoff characteristics: Comparative analysis and universal implications. Water Research 46, 6609-6624. https://doi.org/10.1016/j.watres.2012.07.026

Kayhanian, M., Suverkropp, C., Ruby, A., Tsay, K., 2007. Characterization and prediction of highway runoff constituent event mean concentration. Journal of Environmental Management 85, 279-295. https://doi.org/10.1016/j.jenvman.2006.09.024

Lamprea, K., Bressy, A., Mirande-Bret, C., Caupos, E., Gromaire, M.-C., 2018. Alkylphenol and bisphenol A contamination of urban runoff: an evaluation of the emission potentials of various construction materials and automotive supplies. Environmental Science and Pollution Research 25, 21887-21900. https://doi.org/10.1007/s11356-018-2272-z

LeFevre, G., Paus, K.H., Natarajan, P., Gulliver, J.S., Novak, P.J., Hozalski, R.M., 2014. Review of Dissolved Pollutants in Urban Storm Water and Their Removal and Fate in Bioretention Cells. Journal of Environmental Engineering 141.

Leroy, M., Portet-Koltalo, F., Legras, M., Lederf, F., Moncond'huy, V., Polaert, I., Marcotte, S., 2016. Performance of vegetated swales for improving road runoff quality in a moderate traffic urban area. Science of The Total Environment 566-567, 113-121. https://doi.org/10.1016/j.scitotenv.2016.05.027

Li, H., Davis, A.P., 2009. Water Quality Improvement through Reductions of Pollutant Loads Using Bioretention. Journal of Environmental Engineering 135, 567-576. https://doi.org/10.1061/(ASCE)EE.1943-7870.0000026

Lundy, L., Ellis, J.B., Revitt, D.M., 2012. Risk prioritisation of stormwater pollutant sources. Water Research 46, 6589-6600. https://doi.org/10.1016/j.watres.2011.10.039 
Mackay, D. (Ed.), 2006. Handbook of physical-chemical properties and environmental fate for organic chemicals, 2. ed., ed. ed. CRC/Taylor \& Francis, Boca Raton, Fla.

Markiewicz, A., Björklund, K., Eriksson, E., Kalmykova, Y., Strömvall, A.-M., Siopi, A., 2017. Emissions of organic pollutants from traffic and roads: Priority pollutants selection and substance flow analysis. Science of The Total Environment 580, 1162-1174. https://doi.org/10.1016/j.scitotenv.2016.12.074

McManus, M., Davis, A., 2017. Impact of periodic high concentrations of salts on bioretention nutrients performance. Presented at the 14the IWA/IAHR International Conference on Urban Drain, Prague, pp. 913-915.

MEEM, 2016. Guide technique relatif à l'évaluation de l'état des eaux de surface continentales (cours d'eau, canaux, plans d'eau).

Nielsen, K., Mørch-Madsen, A., Mikkelsen, P., Eriksson, E., 2015. Effect of Disc Filtration with and without Addition of Flocculent on Nano- and Micro-Particles and Their Associated Polycyclic Aromatic Hydrocarbons in Stormwater. Water 7, 1306-1323. https://doi.org/10.3390/w7031306

Norrström, A.C., 2005. Metal mobility by de-icing salt from an infiltration trench for highway runoff. Applied Geochemistry 20, 1907-1919. https://doi.org/10.1016/j.apgeochem.2005.06.002

Peel, M.C., Finlayson, B.L., McMahon, T.A., 2007. Updated world map of the Köppen-Geiger climate classification. Hydrology and Earth System Sciences 11, 1633-1644. https://doi.org/10.5194/hess-11-1633-2007

Roy-Poirier, A., Champagne, P., Filion, Y., 2010. Review of bioretention system research and design: past, present, and future. Journal of Environmental Engineering 136, 878-889.

Sansalone, J.J., Buchberger, S.G., 1997. Partitioning and First Flush of Metals in Urban Roadway Storm Water. Journal of Environmental Engineering 123, 134-143. https://doi.org/10.1061/(ASCE)0733-9372(1997)123:2(134)

Sebastian, C., 2013. Bassin de retenue des eaux pluviales en milieu urbain : performance en matière de piégeage des micropolluants. L'institut national des sciences appliquées de Lyon.

Shainberg, I., Letey, J., 1984. Response of Soils to Sodic and Saline Conditions. Hilgardia 52.

Stachel, B., Holthuis, J.-U., Schulz, W., Seitz, W., Weber, W.H., Tegge, K.-T., Dobner, I., 2010. Treatment Techniques and Analysis of Stormwater Run-off from Roads in Hamburg, Germany, in: Fatta-Kassinos, D., Bester, K., Kümmerer, K. (Eds.), Xenobiotics in the Urban Water Cycle. Springer Netherlands, Dordrecht, pp. 445-461. https://doi.org/10.1007/978-90481-3509-7_24

Stogiannidis, E., Laane, R., 2015. Source Characterization of Polycyclic Aromatic Hydrocarbons by Using Their Molecular Indices: An Overview of Possibilities, in: Whitacre, D.M. (Ed.), Reviews of Environmental Contamination and Toxicology. Springer International Publishing, Cham, pp. 49-133. https://doi.org/10.1007/978-3-319-10638-0_2

Taylor, J.R., 1997. An Introduction to Error Analysis, 2nd ed. University Science Books, Sausalito, California.

Trowsdale, S.A., Simcock, R., 2011. Urban stormwater treatment using bioretention. Journal of Hydrology 397, 167-174. https://doi.org/10.1016/j.jhydrol.2010.11.023

US EPA, 2014. Brake and Tire Wear Emissions from On-road Vehicles in MOVES2014.

U.S. National Library of Medicine, 2018. Hazardous Substances Data Bank.

Winston, R.J., Hunt, W.F., Kennedy, S.G., Wright, J.D., Lauffer, M.S., 2012. Field Evaluation of StormWater Control Measures for Highway Runoff Treatment. Journal of Environmental Engineering 138, 101-111. https://doi.org/10.1061/(ASCE)EE.1943-7870.0000454

Zgheib, S., Moilleron, R., Chebbo, G., 2012. Priority pollutants in urban stormwater: Part 1 - Case of separate storm sewers. Water Research 46, 6683-6692. https://doi.org/10.1016/j.watres.2011.12.012

Zhang, K., Randelovic, A., Page, D., McCarthy, D.T., Deletic, A., 2014. The validation of stormwater biofilters for micropollutant removal using in situ challenge tests. Ecological Engineering 67, 1-10. https://doi.org/10.1016/j.ecoleng.2014.03.004 
